medRxiv preprint doi: https://doi.org/10.1101/2021.12.10.21267604; this version posted December 14, 2021. The copyright holder for this preprint (which was not certified by peer review) is the author/funder, who has granted medRxiv a license to display the preprint in perpetuity.

It is made available under a CC-BY-NC 4.0 International license .

\title{
Shared Inherited Genetics of Benign Prostatic Hyperplasia and Prostate Cancer
}

Alexander Glaser, ${ }^{1,2, *}$ Zhuqing Shi, ${ }^{1, *}$ Jun Wei, ${ }^{1}$ Nadia A. Lanman, ${ }^{3}$ Skylar Ladson-Gary, ${ }^{1}$

Renee E Vickman, ${ }^{1}$ Omar E. Franco,, ${ }^{1}$ Susan E. Crawford, ${ }^{1}$ S. Lilly Zheng, ${ }^{1}$ Simon W.

Hayward, ${ }^{1}$ William B. Isaacs, ${ }^{4}$ Brian T. Helfand, ${ }^{1,2,5 \dagger}$ Jianfeng $\mathrm{Xu}^{1,2,5 \dagger}$

${ }^{1}$ Program for Personalized Cancer Care, ${ }^{2}$ Department of Surgery, NorthShore University HealthSystem, Evanston, IL; ${ }^{3}$ Collaborative Core for Cancer Bioinformatics, Purdue Center for Cancer Research, Purdue University, West Lafayette, IN; ${ }^{4}$ Department of Urology and the James Buchanan Brady Urologic Institute, Johns Hopkins University School of Medicine; Baltimore, MD; ${ }^{5}$ Department of Surgery, University of Chicago Pritzker School of Medicine, Chicago, IL

*These authors contributed equally to this work.

†Corresponding authors: Jianfeng Xu. 1001 University Place, Evanston, IL 60201, U.S.A.

Phone: (224) 264-7501. Fax: (224) 364-7675. E-mail: jxu@northshore.org

Keywords: Benign prostatic hyperplasia (BPH), prostate cancer, heritability, genetic correlation, SNPs, genetic risk score, lethal

Word count of text: 3,203 words (max 3,500 words)

Word count of the abstract: 300 words (max 300 words)

References: $30(\max 30)$

Running Title: Shared inherited genetics of BPH and PCa 


\begin{abstract}
Background: The association between benign prostatic hyperplasia (BPH) and prostate cancer (PCa) remains controversial, largely due to inherent detection bias in traditional observational studies. The objective of this study is to assess their association using inherited SNPs.
\end{abstract}

Methods: Subjects were White men from the large population-based UK Biobank (UKB). Association between BPH and PCa was tested: 1) phenotypical correlation using chi-square test, 2) genetic correlation $\left(r_{\mathrm{g}}\right)$ based on 1,126,841 polymorphic SNPs across the genome using linkage disequilibrium score regression (LDSR), and 3) cross-disease genetic associations based on known risk-associated SNPs (15 for BPH and 239 for PCa), individually and cumulatively as measured by genetic risk score (GRS).

Findings: Among 214,717 White men in the UKB, 24,623 (11.47\%) and 14,311 (6.67\%) had a diagnosis of BPH and PCa, respectively. Diagnoses of these two diseases were significantly correlated, $\chi^{2}=1862.80, P<1 \mathrm{E}-299$. A significant genetic correlation was found, $r_{\mathrm{g}}(95 \%$ confidence interval $(\mathrm{CI}))=0.27(0.15-0.39), P=9.17 \mathrm{E}-06$. In addition, significant cross-disease genetic associations for established risk-associated SNPs were also found. Among the 250 established GWAS-significant SNPs of PCa or BPH, 51 were significantly associated with risk of the other disease at $P<0.05$, significantly more than expected by chance (N=12), $P=3.04 \mathrm{E}-7$ ( $\chi^{2}$-test). Furthermore, significant cross-disease GRS associations were also found; GRS $S_{\mathrm{BPH}}$ was significantly associated with PCa risk (odds ratio $(\mathrm{OR})=1.26(1.18-1.36), P=1.62 \mathrm{E}-10)$, and GRSPCa was significantly associated with BPH risk $(\mathrm{OR}=1.03$ (1.02-1.04), $P=8.57 \mathrm{E}-06)$. Moreover, $\mathrm{GRS}_{\mathrm{BPH}}$ was significantly and inversely associated with lethal PCa risk in a PCa case-case analysis (OR=0.58 (0.41-0.81), P=1.57E03). In contrast, GRSPCa was not significantly associated with lethal PCa (OR=0.99 (0.941.04), $P=0.79)$.

Interpretation: BPH and PCa share common inherited genetics which suggests the phenotypical association of these two diseases in observational studies is not entirely caused by detection bias. This novel finding may have implications in disease etiology and risk stratification. 
medRxiv preprint doi: https://doi.org/10.1101/2021.12.10.21267604; this version posted December 14, 2021. The copyright holder for this preprint (which was not certified by peer review) is the author/funder, who has granted medRxiv a license to display the preprint in perpetuity.

It is made available under a CC-BY-NC 4.0 International license .

Funding: None. 


\section{Introduction}

Benign prostatic hyperplasia (BPH) is a histological diagnosis characterized by a proliferation of both stromal and epithelial cells in the transitional zone of the prostate. ${ }^{1}$ This proliferation can lead to bladder outlet obstruction and subsequent lower urinary tract symptoms (LUTS). Prostate cancer (PCa), on the other hand, is a malignant adenocarcinoma primarily found in the peripheral zone of the prostate and, prior to metastasis is typically asymptomatic being primarily detected by PSA-screening. ${ }^{2}$ BPH and PCa are two of the most common diseases in men and incidence for both conditions increases considerably with age. ${ }^{3,4}$ These two pathologic processes negatively impact quality of life and result in considerable healthcare expense.

Despite the major differences in cellular growth patterns and stereotyped locations within the prostate, a link between BPH and PCa has been hypothesized, studied and reported.5, 6 Their co-occurrence was first documented from autopsy studies in 1957 and 1992.7, 8 Since then, conflicting results on the association have been published in multiple epidemiological studies, including those from retrospective case-control studies,9, 10 prospective cohorts, ${ }^{10}$ secondary analysis of clinical trials, ${ }^{11,12}$ large population-based cohorts, ${ }^{13,14}$ and a recent meta-analysis. ${ }^{15}$ To date, no consensus has been reached on their association and causal relationship. ${ }^{6}$ Consequently, the current National Cancer Institute website states that 'BPH is not linked to cancer and does not increase your risk of getting PCa'.16

A major cause for the inconclusive findings is the inherent detection bias of observational studies in diagnosing these two diseases. Patients treated by urologists for one of these diseases (e.g., BPH) are more likely to be examined thoroughly and are therefore more likely to be diagnosed for the other disease (PCa). ${ }^{17}$ This detection bias is particularly prominent because the likelihood of diagnosing BPH and PCa increases with heightened prostate examinations and diagnostic evaluations that include prostate-specific antigen (PSA) measurements, which is included in current guidelines for each of these disease states. ${ }^{18,19}$ 
medRxiv preprint doi: https://doi.org/10.1101/2021.12.10.21267604; this version posted December $14,2021$. The copyright holder for this preprint (which was not certified by peer review) is the author/funder, who has granted medRxiv a license to display the preprint in perpetuity.

It is made available under a CC-BY-NC 4.0 International license .

The availability of high-throughput SNP genotyping technology in the last 15 years enabled a systematic evaluation of genetic variants in the genome among large numbers of subjects. This technology advanced the understanding of the polygenic architecture of common diseases in two distinct ways. First, using millions of SNPs in the genome, it is now possible to estimate polygenic heritability of a disease using linkage disequilibrium score regression (LDSR). ${ }^{20}$ Furthermore, unbiased estimates of SNP-based genetic correlation between two diseases can be obtained using LDSR. Second, it is also feasible to systematically compare genetic variants in the genome in subjects with or without a disease using genome-wide association studies (GWAS) to identify disease risk-associated SNPs. Owing to the rigorous requirement of statistical significance $(P<2 \mathrm{E}-08)$ and confirmation in independent studies, risk-associated SNPs identified by GWAS most likely represent true associations. To date, 269 and 17 risk-associated SNPs have been identified for PCa and BPH, respectively. ${ }^{21,22}$ Although the effect of these risk-associated SNPs is moderate individually, they are additive and have a stronger cumulative effect that can be measured by a polygenic risk score. Published studies have consistently demonstrated the performance of polygenic risk score for measuring and stratifying inherited risk. ${ }^{21-24}$ Due to the inherited nature of SNPs (fixed at conception and always preceding occurrence of diseases), they are less susceptible to detection bias in assessing associations of two diseases from observational studies.

The primary hypothesis of this study is that BPH and PCa are linked and that this association is partially contributed by shared inherited genetics via the same genes (causal or pleotropic effects) and/or different genes in linkage disequilibrium (LD). This hypothesis was tested in a large population-based cohort by 1) assessing phenotypical associations between the two diseases, 2) estimating their genetic correlation based on millions of SNPs in the genome using LDSR, and 3) performing cross-disease genetic association tests based on known risk-associated SNPs, individually and cumulatively. Furthermore, the clinical utilities of polygenic risk score of BPH and PCa for predicting the risk of these two diseases were also assessed.

\section{Methods}




\section{Subjects}

Subjects of this study were from the UK Biobank (UKB), a population-based study with extensive genetic and phenotypic data for approximately 500,000 individuals from across the United Kingdom aged between 40 and 69 at recruitment (accessed under Application Number: 50295). ${ }^{25}$ Extensive phenotypic and genomic information is available for each participant in the UKB, including disease diagnosis, questionnaire, biological measurements, lifestyle indicators, and biomarkers in blood and urine. Diagnoses of BPH (Data-Field 132073) and the procedure for transurethral resection of the prostate (TURP) (Data-Field 41200, 41210 and 41272), as well as diagnosis of PCa (Data-Field 40001, $40002,40006,41202,41204,41270$ ) were provided by the UKB based on the ICD-10 code and/or self-reports (released on July 9th 2021 ). Information on PCa-specific death (lethal PCa) was based on death registries. Genome-wide SNPs data are available for all participants.

\section{SNPs and polygenic risk score}

Independent risk-associated SNPs for BPH and PCa included in this study were established using evidence-based review of published GWAS (defined as $P<5 \times 10^{-8}$ and pair-wise linkage disequilibrium (LD, $\left.r^{2}<0.2\right)$ ) and are available in the UKB, including 15 for BPH and 239 for PCa. Their SNP ID, risk and reference alleles, odds ratio, allele frequency, and references are described in sTable 1.

The cumulative effect of SNPs on each disease was measured by genetic risk score (GRS), a population-standardized polygenic risk score. GRS was calculated by multiplying the per-allele odds ratio (OR) with number of risk alleles of each SNP and normalizing the risk by the average risk expected in the population. ${ }^{26}$ As such, GRS value can be interpreted as relative risk to the general population regardless number of risk-associated SNPs used in GRS calculation.

\section{Statistical analysis}

Correlation between BPH and PCa was assessed using a chi-square test. The strength of association (OR and 95\% confidence interval (CI)) between the two diseases 
was estimated using a multivariable logistic regression adjusting for age at recruitment and genetic background (top 10 principal components provided by the UKB).

SNP-based heritability $\left(h^{2}\right)$ for BPH and PCa, respectively, and genetic correlation $\left(r_{\mathrm{g}}\right)$ between BPH and PCa were estimated based on polymorphic SNPs (minor allele frequency >0.01) in the genome using LDSR analysis. ${ }^{20}$ GWAS summary statistics of BPH and PCa (adjusting for age at recruitment and genetic background) were matched to the pre-computed LD scores of the 1000 Genomes European reference. SNP heritability estimates were converted to the liability-scale based on the observed prevalence in the UKB.

Cross-disease genetic association for BPH and PCa was tested based on known riskassociated SNPs (individually and cumulatively as measured by GRS) of these two diseases. Association of individual SNPs and GRS with cross-disease risk was tested adjusting for age at recruitment and genetic background.

\section{Results}

Among 214,717 White men in the UKB, 24,623 (11.47\%) and 14,311 (6.67\%) had a diagnosis of BPH and PCa, respectively (Table 1). Diagnoses of these two diseases were significantly correlated, $\chi^{2}=1862.80, P<1 \mathrm{E}-299$. Specifically, 3,231 (1.50\%) men had a diagnosis of both BPH and PCa, which was significantly higher than the 1,332 (0.62\%) expected assuming that the diagnosis of these diseases were independent, $\chi^{2}=797.96$, $P=1.50 \mathrm{E}-175$. Having a diagnosis of PCa was associated with an OR (95\% CI) of 1.58 (1.511.65) for BPH risk, $P=5.13 \mathrm{E}-94$. Conversely, having a diagnosis of BPH was associated with an OR (95\%CI) of 1.57 (1.50-1.64) for PCa risk, $P=1.07 \mathrm{E}-90$. These ORs were estimated adjusting for age at recruitment and genetic background.

Genetic susceptibility to BPH and PCa was estimated based on polymorphic SNPs across the genome (minor allele frequency >1\%). SNP-based heritability $\left(h^{2}\right)(95 \% \mathrm{CI}$ ) was $0.09(0.07-0.11)$ for BPH $(P=0.005)$ and $0.15(0.12-0.18)$ for PCa ( $P=4.87 \mathrm{E}-10)$ (Figure 1). Furthermore, a significant and positive genetic correlation between the two diseases was found, $r_{\mathrm{g}}(95 \% \mathrm{CI})$ was 0.27 (0.15-0.39), $P=9.17 \mathrm{E}-06$. 
When examining established risk-associated SNPs for BPH and PCa, significant cross-disease genetic associations were found. Among the 250 risk-associated SNPs of PCa or BPH from previous GWAS studies, 51 were significantly associated with risk of the other disease at $P<0.05$, which was significantly more than expected by chance $(\mathrm{N}=12), P=3.04 \mathrm{E}$ 7 ( $\chi^{2}$-test). Specifically, among the 239 established independent PCa risk-associated SNPs, 45 were associated with BPH diagnosis at $P<0.05$ (sTable 1). Reciprocally, among the 15 established independent BPH risk-associated SNPs, 10 were associated with PCa diagnosis at $P<0.05$. It is noted that 4 established GWAS-significant risk-associated SNPs of PCa and BPH were overlapped.

We also evaluated the cumulative effect of SNPs on disease risk. In addition to highly significant association between disease-specific GRS and their respective disease risks, significant cross-disease associations were also found (Table 2). GRS based on the 15 established BPH risk-associated SNPs was positively associated with PCa diagnosis $(\mathrm{OR}=1.26, P=1.62-\mathrm{E}-10)$. Similarly, GRS based on the 239 established PCa risk-associated SNPs (GRSPCa) was significantly associated with BPH diagnosis $(\mathrm{OR}=1.03, P=8.57 \mathrm{E}-06)$.

Furthermore, GRS was also associated with specific phenotypes of BPH and PCa (Table 2). Notably, GRS $\mathrm{BPH}$ was inversely associated with lethal PCa risk when comparing lethal PCa cases vs. non-lethal PCa cases $(\mathrm{OR}=0.58, P=1.57 \mathrm{E}-03)$. Upon examining results by GRS $_{\text {BPH }}$ deciles (sTable 2), while no trend of lethal PCa prevalence with GRS BPH $_{\text {deciles was }}$ found $(P=0.14)$, the prevalence of lethal PCa in men of the highest $\mathrm{GRS}_{\mathrm{BPH}}$ decile was $0.23 \%$, noticeably lower than that of remaining deciles $(0.33 \%, P=0.02)$. In contrast, the prevalence of non-lethal PCa increased slightly with higher $\mathrm{GRS}_{\mathrm{BPH}}$ deciles $\left(P_{\text {trend }}=0.01\right)$, with the highest rate (6.64\%) found in men of the top $\mathrm{GRS}_{\mathrm{BPH}}$ decile. As for GRSPCa, no association with lethal PCa was found in a case-case analysis (OR=0.99, $P=0.79$ ) GRSPCa, it was not associated with lethal PCa in case-case analysis ( $O R=0.99, P=0.79)$. The prevalence of both lethal PCa and non-lethal PCa increased by each decile at a similar scale (sTable 2).

In light of the genetic correlation and cross-disease association of GRS between these two diseases, we next explored the clinical utility of using two GRS values for predicting diagnosis of BPH, PCa, and both diseases (Table 3, Figure 2). For example, using a GRS of 1.5 as a cutoff value (i.e., 1.5-fold increased risk over the general population), men 
with both high GRS BPH $_{\text {and GRSPCa }}$ had a considerably higher prevalence of these two diseases compared to men with both low GRS $\mathrm{BPH}_{\mathrm{PH}}$ and GRSPCa; $15.64 \%$ vs. $5.12 \%$ for PCa, $16.87 \%$ vs. $11.18 \%$ for BPH, and $3.76 \%$ vs. $1.19 \%$ for both BPH and PCa. Similarly, men with either high $\mathrm{GRS}_{\mathrm{BPH}}$ or GRSPCa had higher prevalence of these two diseases. For lethal PCa, men with low GRS $_{\text {BPH }}$ and high GRSPCa had a higher prevalence $(0.68 \%)$ than those with both low GRS (0.25\%) and especially those with high GRS BPH $_{\text {but low GRSPa }}(0.11 \%)$. Regarding surgical intervention for BPH (TURP), men with high GRSBPH had a higher prevalence of TURP than those with low $\mathrm{GRS}_{\mathrm{BPH}}$, regardless of GRSPCa $(6.54 \%$ and $7.40 \%$ for

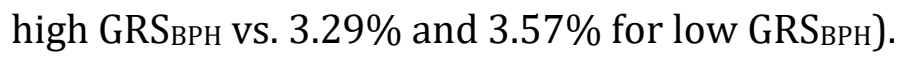

\section{Discussion}

The primary goal of this study is to address the longstanding controversy surrounding the link between BPH and PCa. ${ }^{5-15}$ This clinically important question is complicated primarily by the inherent detection bias in epidemiological studies where patients diagnosed with one disease are typically examined more thoroughly by urologists and therefore have a higher chance of being diagnosed with the other disease. ${ }^{17}$ It is practically impossible to estimate the degree (partially or total) of the detection bias contributing to the observed association of BPH and PCa in traditional studies. Utilizing a large population-based cohort of over 200,000 men with diagnostic information for both diseases and genome-wide SNP data, we are able to test the association using both traditional epidemiological and alternative inherited genetic approaches (Figure 1). We 1) demonstrated a statistical association of phenotypical diagnoses of BPH and PCa $(P<1 \mathrm{E}-$ 299), 2) revealed a polygenic inherited basis for each of these two diseases $\left(h^{2}\right.$ of 0.09 and 0.16 for BPH and PCa, respectively), and 3) more importantly, the present analysis suggests that these two diseases are genetically correlated and that they share part of a polygenic background ( $\left.r_{\mathrm{g}}=0.27\right)$ and risk-associated SNPs. A genetic correlation measures the proportion of the heritability $\left(h^{2}\right)$ that is shared between two diseases divided by the square root of the product of the heritability for each disease. This alternative inherited genetic approach does not directly test phenotypical co-occurrence of two diseases. Instead, it tests the correlation between heritability of each individual disease which is 
estimated only from the respective diseases, and therefore is not susceptible to detection bias. These findings provide strong statistical evidence that diagnoses of BPH and PCa are linked and the excessed concurrence of these two diseases was in part contributed by inherited genetics and not entirely driven by detection bias.

Shared inherited risk between BPH and PCa may arise from several potential sources, including 1) LD of different genes for BPH and PCa in the same chromosomal region, 2) pleiotropy where a single gene or variant affects both BPH and PCa, 3) causal effect where a gene causes a disease first which in turn causes the other disease, and 4) biases from population stratification. While the likelihood for the last source is low because this study was based on White men from a population-based cohort and the analysis adjusted for population stratification, we cannot differentiate among the sources of LD, pleiotropy and causality. Therefore, we can only conclude that shared inherited risk is directly or indirectly associated with both BPH and PCa but does not necessary directly cause these two diseases.

Although Mendelian randomization (MR) analysis is a well-established method utilizing measured inherited germline variations (genetic instruments) to interrogate the causal effect of an exposure on an outcome, ${ }^{27}$ we did not perform an MR analysis in this study for the following two considerations. First, considering the major difference between the two diseases in pathophysiology (benign proliferation for BPH and malignant growth for PCa), anatomic locations (primarily transition zone for BPH and peripheral zone for $\mathrm{PCa}$ ), and cell types (epithelial and stromal hyperplasia for $\mathrm{BPH}$; epithelial malignant transformation for $\mathrm{PCa}$ ), we do not hypothesize that the development of either one of these two diseases is an exposure that causes the other disease. Second, it is challenging to test the validity of key assumptions underlying MR analysis (independent and exclusion). ${ }^{28}$ The independent assumption states that there are no unmeasured confounders of the associations between genetic variants and outcome. The exclusion restriction assumption requires that the genetic variants affect the outcome only through their effect on the risk factor of interest. Therefore, it is difficult to interpret MR results even if they are statistically significant. 
medRxiv preprint doi: https://doi.org/10.1101/2021.12.10.21267604; this version posted December $14,2021$. The copyright holder for this preprint (which was not certified by peer review) is the author/funder, who has granted medRxiv a license to display the preprint in perpetuity.

It is made available under a CC-BY-NC 4.0 International license .

As a comparison, we performed a similar analysis to assess the association and genetic correlation between BPH and another urological cancer (bladder cancer). While the diagnoses of these two diseases were highly correlated ( $\left.\chi^{2}=1615.00, P<1 \mathrm{E}-299\right)$, there was no significant genetic correlation between the two diseases $\left(r_{\mathrm{g}}=0.01, P=0.93\right)$. These results suggest that unlike BPH and PCa where the observed link is partially explained by shared inherited risk, there is no evidence that BPH and bladder share inherited genetic risk. The observed link between BPH and bladder cancer may be largely or completely caused by detection bias.

The finding of shared inherited risk between BPH and PCa from this study may have implications in understanding etiology and clinical utility. For example, identifying commonality of genes in the chromosomal regions that are associated with both BPH and PCa may help to better understand etiology for these two diseases. Toward this effort, we performed a preliminary pathway analysis for the 65 nearest genes in the 51 independent regions associated with both BPH and PCa using KEGG (Kyoto Encyclopedia of Genes and Genomes) (sTable 3). These genes are significantly enriched in only one biological pathway, the PCa pathway, $P=0.007$ (Benjamini correction) (sTable 4). Five ( $A R, K L K 3$, TP53, FGFR2, and NKX3-1) of the 65 genes (7.69\%) are involved in the PCa pathway, significantly more than expected by chance ( 88 of 6,879 genes $(1.28 \%$ ) in the KEGG are in the PCa pathway). Similar results were found in the Ingenuity Pathway Analysis (version 01-20-04, Qiagen, CA). A major caveat of this analysis is that nearest genes may or may not account for the observed genetic associations, a common challenge for understanding biological mechanisms of GWAS findings.

The genetic correlation between the two diseases, especially cross-disease genetic

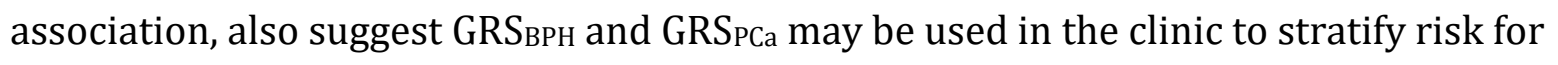
these two diseases. For example, men with either or both high GRS ${ }_{B P H}$ and GRSPCa have higher risks for these two diseases, alone or both, and men with high GRSвPн are more likely to undergo surgical intervention. Men identified as high risk for these disease states may benefit from more aggressive screening and/or earlier referral to urologic sub-specialists.

While confirming the previous null result that GRSPCa does not differentiate aggressiveness of the disease in PCa patients, ${ }^{21,24,29}$ we obtained a novel finding that 
medRxiv preprint doi: https://doi.org/10.1101/2021.12.10.21267604; this version posted December $14,2021$. The copyright holder for this

$\mathrm{GRS}_{\mathrm{BPH}}$ is inversely associated with lethal PCa in a case-case analysis. Specifically, men with

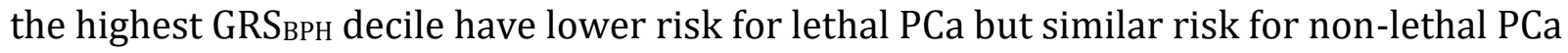
when comparing to men in the remaining deciles. This finding is important and plausible considering that 1) $\mathrm{GRS}_{\mathrm{BPH}}$ is positively associated with prostate volume, ${ }^{22}$ and 2) prostate volume is inversely associated with aggressive $\mathrm{PCa} .{ }^{30}$ However, additional studies are needed to confirm this novel finding before exploring its clinical utility. Furthermore, more studies are warranted to understand specific SNPs and genes underlying this association and their biological effects on lethal PCa. Large PCa patient cohorts with germline data, PSA measurement, prostate volume, Gleason grade at time of diagnosis and prostatectomy surgery, as well as long-term disease follow-up are crucial to confirm and understand the association.

Several limitations of this study are noted. First, due to the fact that 95\% of subjects in the UKB are White, our analyses and conclusions were limited to this group only. The generalizability of our finding in other ethnic and racial populations needs to be evaluated. Second, it is recognized that the UKB cohort was included in a previous GWAS that identified BPH risk-associated SNPs. ${ }^{22}$ Although this may inflate performance of GRS $_{B P H}$ for predicting BPH risk, it has limited impact on the key findings of genetic correlation. Third, a lack of detailed clinical variables relevant to BPH and PCa in this population-based biobank such as PSA measurement, prostate volume, Gleason grade, and quantification of lower urinary tract symptoms hinder more granular analysis and understanding of clinical and genetic associations. Some findings from this study, especially the inverse association between $\mathrm{GRS}_{\mathrm{BPH}}$ and lethal PCa, should be considered as preliminary. Comprehensive analysis in large and clinically well-characterized urological patient cohorts are needed. Finally, we did not perform functional analysis to investigate the biological mechanism of the genetic associations for both BPH and PCa. This is in part due to the nature of this genetic study where the primary goal is to identify chromosomal regions with statistical evidence for association. More importantly, we recognize the substantial challenges in these functional studies. The chromosomal region for each genetic association is typically large ( $>500 \mathrm{~kb}$ ) and many of these regions are outside of coding genes. Nevertheless, we feel genetic association studies provide critical data relevant to 
medRxiv preprint doi: https://doi.org/10.1101/2021.12.10.21267604; this version posted December 14, 2021. The copyright holder for this preprint (which was not certified by peer review) is the author/funder, who has granted medRxiv a license to display the preprint in perpetuity.

It is made available under a CC-BY-NC 4.0 International license .

human diseases. Geneticists and biologists can collaborate to understand biological mechanisms of genetic associations.

\section{Conclusions}

In conclusion, utilizing genome-wide SNP data from a large population-based cohort demonstrated that BPH and PCa share common polygenic inherited risk. This novel genetic result suggests the excess of co-occurrence of these two diseases is not completely driven by detection bias. The current conclusion that $\mathrm{BPH}$ and $\mathrm{PCa}$ are not related, as stated by the $\mathrm{NCI}$ and other authoritative agencies, may be reconsidered. 


\section{Figure legends}

Figure 1. Summary of findings for the phenotypic and genetic link between BPH and PCa in White men of the UKB. First, diagnoses of BPH and PCa were significantly correlated (bidirection arrows on the right side, $P<1 \mathrm{E}-299$ ). Second, inherited polygenic background contributed to the diagnosis of each disease (horizontal arrows, $h^{2}$ of 0.09 and 0.16 for BPH and PCa, respectively). Third, polygenic background for BPH and PCa were significantly correlated (bi-direction arrows on the left side, $r_{\mathrm{g}}=0.27, P=9$.17E-06). Lastly, cross-disease association of established risk-associated SNPs for BPH and PCa (diagonal arrows). These findings provide strong statistical evidence that diagnoses of BPH and PCa are linked and the excessed co-occurrence of these two diseases was in part contributed by inherited genetics and not entirely driven by detection bias.

Figure 2. Pie charts of prevalence for BPH and PCa diagnoses in four groups of men with low ( $<1.5)$ and high $(\geq 1.5)$ GRS $_{\text {BPH }}$ and GRSPCa: a) both low, b) low GRS BPH $_{\text {and high GRSPCa, }}$ c) high GRS ${ }_{\mathrm{BPH}}$ and low GRSPCa, and d) both high. The percentage of men is each GRS group is indicated under each pie chart. Blue, green, and red slices represent the prevalence of $\mathrm{PCa}, \mathrm{BPH}$, and both diseases, respectively. 
medRxiv preprint doi: https://doi.org/10.1101/2021.12.10.21267604; this version posted December 14, 2021. The copyright holder for this preprint (which was not certified by peer review) is the author/funder, who has granted medRxiv a license to display the preprint in perpetuity.

It is made available under a CC-BY-NC 4.0 International license .

\section{Acknowledgements}

We are grateful to the Ellrodt-Schweighauser family for establishing Endowed Chair

of Cancer Genomic Research (Xu), and Chez and Melman families for establishing Endowed Chairs of Personalized Prostate Cancer Care (Helfand), as well as the Rob Brooks Fund for Personalized Prostate Cancer Care at NorthShore University HealthSystem. 
medRxiv preprint doi: https://doi.org/10.1101/2021.12.10.21267604; this version posted December 14, 2021. The copyright holder for this preprint (which was not certified by peer review) is the author/funder, who has granted medRxiv a license to display the preprint in perpetuity. It is made available under a CC-BY-NC 4.0 International license.

\section{Author Contributions}

Concept and design: $\mathrm{Xu}$, Helfand, Glaser

Data analysis: Shi, Wei, Lanman

Manuscript draft: Xu, Helfand, Glaser

Critical revision of the manuscript for important intellectual content: Glaser, Shi, Wei,

Lanman, Ladson-Gary, Vickman, Franco, Crawford, Zheng, Hayward, Isaacs, Helfand, Xu

Supervision: $\mathrm{Xu}$ and Helfand 
medRxiv preprint doi: https://doi.org/10.1101/2021.12.10.21267604; this version posted December 14, 2021. The copyright holder for this preprint (which was not certified by peer review) is the author/funder, who has granted medRxiv a license to display the preprint in perpetuity. It is made available under a CC-BY-NC 4.0 International license.

\section{Ethical approval and consent to participate}

The UK Biobank was approved by North West - Haydock Research Ethics

Committee (REC reference: 16/NW/0274; IRAS project ID: 200778). Data from the UK

Biobank was accessed through a Material Transfer Agreement under Application Reference

Number: 50295. This study was performed in accordance with the Declaration of Helsinki. 
medRxiv preprint doi: https://doi.org/10.1101/2021.12.10.21267604; this version posted December 14, 2021. The copyright holder for this preprint (which was not certified by peer review) is the author/funder, who has granted medRxiv a license to display the preprint in perpetuity. It is made available under a CC-BY-NC 4.0 International license.

\section{Data availability}

The data used in this study is available in the UK Biobank, a publicly available repository. Data was accessed through a Material Transfer Agreement under Application Reference Number: 50295. For additional information, please feel free to contact the corresponding author, Jianfeng Xu, DrPH. 
medRxiv preprint doi: https://doi.org/10.1101/2021.12.10.21267604; this version posted December 14, 2021. The copyright holder for this preprint (which was not certified by peer review) is the author/funder, who has granted medRxiv a license to display the preprint in perpetuity.

It is made available under a CC-BY-NC 4.0 International license .

\section{Competing Interests statement}

NorthShore University HealthSystem has an agreement with GoPath Laboratories

for genetic tests of polygenic risk score. 


\section{REFERENCES}

1. Roehrborn CG. Pathology of benign prostatic hyperplasia. Int J Impot Res 20 Suppl 3), S11-8 (2008).

2. McNeal JE, Redwine EA, Freiha FS, Stamey TA. Zonal distribution of prostatic adenocarcinoma. Correlation with histologic pattern and direction of spread. Am J Surg Pathol 12 (12), 897-906 (1988).

3. Berry SJ, Coffey DS, Walsh PC, Ewing LL. The development of human benign prostatic hyperplasia with age. J Urol 132 (3), 474-9 (1984).

4. Siegel RL, Miller KD, Fuchs HE, Jemal A. Cancer Statistics, 2021. CA Cancer J Clin 71 (1), 7-33 (2021).

5. Alcaraz A, Hammerer P, Tubaro A, Schroder FH, Castro R. Is there evidence of a relationship between benign prostatic hyperplasia and prostate cancer? Findings of a literature review. Eur Urol 55 (4), 864-73 (2009).

6. Orsted DD, Bojesen SE. The link between benign prostatic hyperplasia and prostate cancer. Nat Rev Urol 10 (1), 49-54 (2013).

7. Sommers SC. Endocrine changes with prostatic carcinoma. Cancer 10 (2), 345-58 (1957).

8. Bostwick DG, Cooner WH, Denis L, Jones GW, Scardino PT, Murphy GP. The association of benign prostatic hyperplasia and cancer of the prostate. Cancer 70 (1 Suppl), 291-301 (1992).

9. Greenwald P, Kirmss V, Polan AK, Dick VS. Cancer of the prostate among men with benign prostatic hyperplasia. J Natl Cancer Inst 53 (2), 335-40 (1974).

10. Armenian HK, Lilienfeld AM, Diamond EL, Bross ID. Relation between benign prostatic hyperplasia and cancer of the prostate. A prospective and retrospective study. Lancet 2 (7873), 115-7 (1974).

11. Thompson IM, Coltman CA, Jr., Crowley J. Chemoprevention of prostate cancer: the Prostate Cancer Prevention Trial. Prostate 33 (3), 217-21 (1997).

12. Andriole GL, Bostwick DG, Brawley OW, Gomella LG, Marberger M, Montorsi F, et al. Effect of dutasteride on the risk of prostate cancer. N Engl J Med 362 (13), 1192-202 (2010).

13. Chokkalingam AP, Nyren O, Johansson JE, Gridley G, McLaughlin JK, Adami HO, et al. Prostate carcinoma risk subsequent to diagnosis of benign prostatic hyperplasia: a population-based cohort study in Sweden. Cancer 98 (8), 1727-34 (2003).

14. Orsted DD, Bojesen SE, Nielsen SF, Nordestgaard BG. Association of clinical benign prostate hyperplasia with prostate cancer incidence and mortality revisited: a nationwide cohort study of 3,009,258 men. Eur Urol 60 (4), 691-8 (2011).

15. Zhang L, Wang Y, Qin Z, Gao X, Xing Q, Li R, et al. Correlation between Prostatitis, Benign Prostatic Hyperplasia and Prostate Cancer: A systematic review and Metaanalysis. J Cancer 11 (1), 177-89 (2020).

16. National Cancer Institute. Understanding Prostate Changes: A Health Guide for Men 2021. https://www.cancer.gov/types/prostate/understanding-prostate-changes (accessed 3 Nov 2021) 
17. Meigs JB, Barry MJ, Giovannucci E, Rimm EB, Stampfer MJ, Kawachi I. High rates of prostate-specific antigen testing in men with evidence of benign prostatic hyperplasia. Am J Med 104 (6), 517-25 (1998).

18. Lerner LB, McVary KT, Barry MJ, Bixler BR, Dahm P, Das AK, et al. Management of Lower Urinary Tract Symptoms Attributed to Benign Prostatic Hyperplasia: AUA GUIDELINE PART I-Initial Work-up and Medical Management. J Urol 206 (4), 80617 (2021).

19. Carroll PR, Parsons JK, Andriole G, Bahnson RR, Castle EP, Catalona WJ, et al. NCCN Guidelines Insights: Prostate Cancer Early Detection, Version 2.2016. J Natl Compr Canc Netw 14 (5), 509-19 (2016).

20. Ni G, Moser G, Schizophrenia Working Group of the Psychiatric Genomics C, Wray NR, Lee SH. Estimation of Genetic Correlation via Linkage Disequilibrium Score Regression and Genomic Restricted Maximum Likelihood. Am J Hum Genet 102 (6), 1185-94 (2018).

21. Conti DV, Darst BF, Moss LC, Saunders EJ, Sheng X, Chou A, et al. Trans-ancestry genome-wide association meta-analysis of prostate cancer identifies new susceptibility loci and informs genetic risk prediction. Nat Genet 53 (1), 65-75 (2021).

22. Gudmundsson J, Sigurdsson JK, Stefansdottir L, Agnarsson BA, Isaksson HJ, Stefansson OA, et al. Genome-wide associations for benign prostatic hyperplasia reveal a genetic correlation with serum levels of PSA. Nat Commun 9 (1), 4568 (2018).

23. Zheng SL, Sun J, Wiklund F, Smith S, Stattin P, Li G, et al. Cumulative association of five genetic variants with prostate cancer. N Engl J Med 358 (9), 910-9 (2008).

24. Shi Z, Platz EA, Wei J, Na R, Fantus RJ, Wang CH, et al. Performance of Three Inherited Risk Measures for Predicting Prostate Cancer Incidence and Mortality: A Population-based Prospective Analysis. Eur Urol), (2020).

25. Bycroft C, Freeman C, Petkova D, Band G, Elliott LT, Sharp K, et al. The UK Biobank resource with deep phenotyping and genomic data. Nature 562 (7726), 203-9 (2018).

26. Yu H, Shi Z, Wu Y, Wang CH, Lin X, Perschon C, et al. Concept and benchmarks for assessing narrow-sense validity of genetic risk score values. Prostate 79 (10), 1099105 (2019).

27. Burgess S, Butterworth A, Thompson SG. Mendelian randomization analysis with multiple genetic variants using summarized data. Genet Epidemiol 37 (7), 658-65 (2013).

28. Burgess S, Davey Smith G, Davies NM, Dudbridge F, Gill D, Glymour MM, et al. Guidelines for performing Mendelian randomization investigations. Wellcome Open Res 4), 186 (2019).

29. Xu J, Isaacs SD, Sun J, Li G, Wiley KE, Zhu Y, et al. Association of prostate cancer risk variants with clinicopathologic characteristics of the disease. Clin Cancer Res 14 (18), 5819-24 (2008).

30. Yamashiro JR, de Riese WTW. Any Correlation Between Prostate Volume and Incidence of Prostate Cancer: A Review of Reported Data for the Last Thirty Years. Res Rep Urol 13), 749-57 (2021). 


\section{Figure 1}

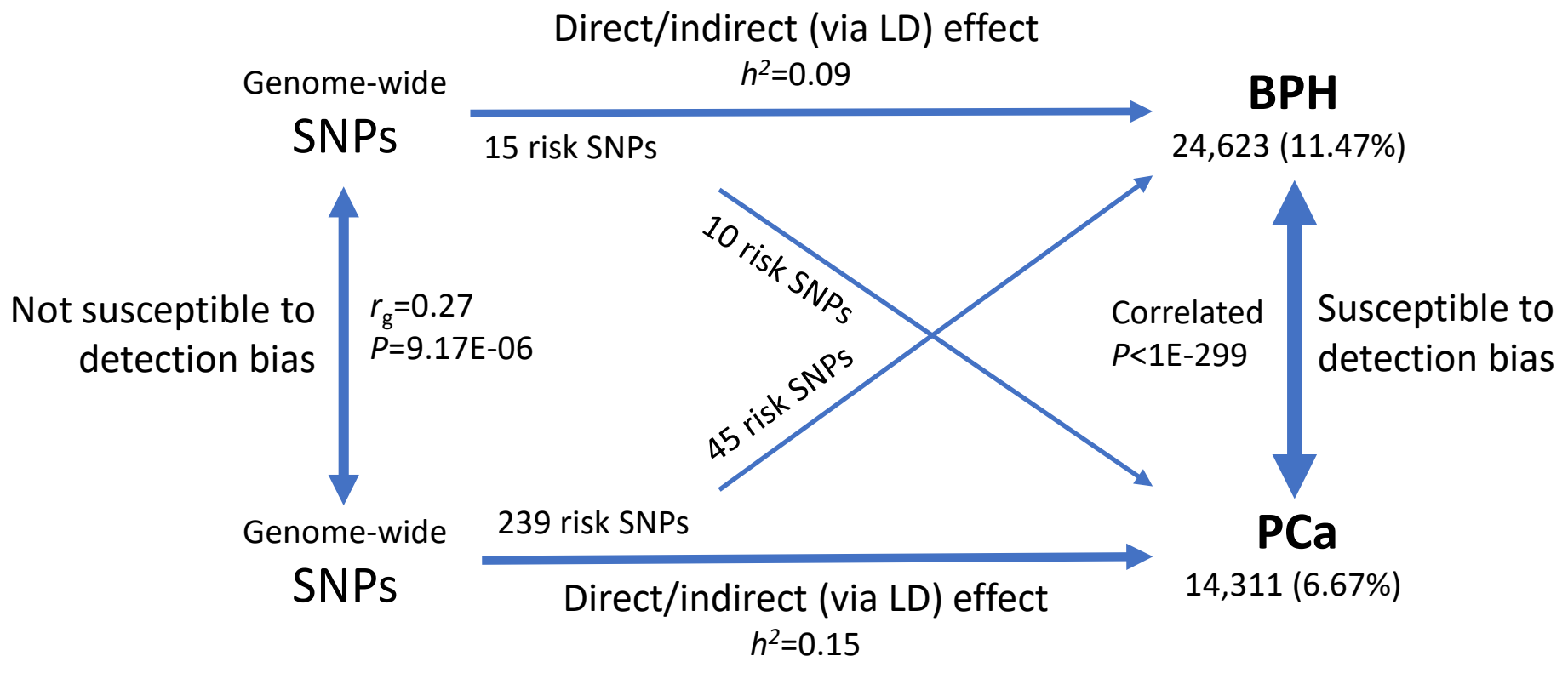


Figure 2

a: Low $\mathrm{GRS}_{\mathrm{BPH}}$ and low $\mathrm{GRS}_{\mathrm{PCa}}$

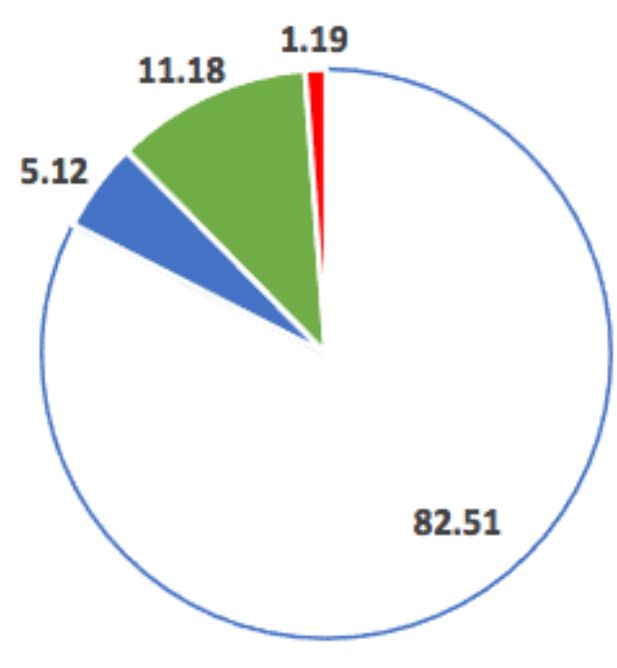

$80.31 \%$ b: Low $\mathrm{GRS}_{\mathrm{BPH}}$ and high $\mathrm{GRS}_{\mathrm{PCa}}$

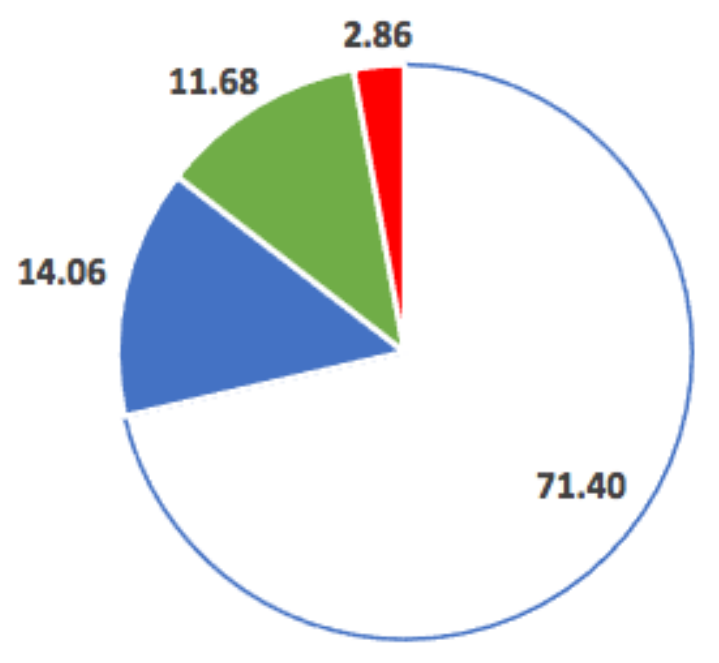

$16.19 \%$ c: High $\mathrm{GRS}_{\mathrm{BPH}}$ and low $\mathrm{GRS}_{\mathrm{PCa}}$

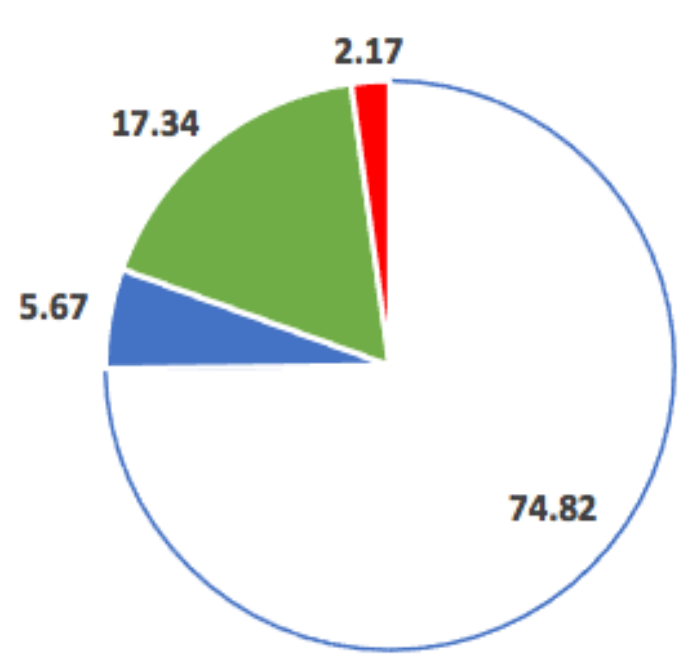

$2.84 \%$ d: High $\mathrm{GRS}_{\mathrm{BPH}}$ and high $\mathrm{GRS}_{\mathrm{PCa}}$

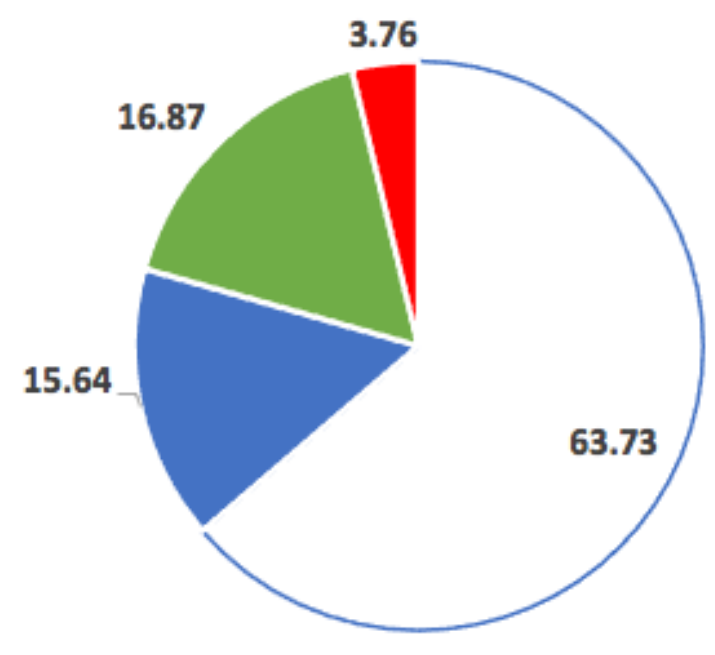

$0.66 \%$ 
Table 1. Diagnosis of BPH and PCa among White men in the UKB $(N=214,717)$

\begin{tabular}{llll}
\hline & & \multicolumn{2}{c}{ Median age (IQR), yr } \\
Diagnosis & No. (\%) of men & At recruitment & Age at diagnosis \\
\hline BPH & & & \\
$\quad$ Any BPH & $24,623(11.47)$ & $63.5(60.5-66.5)$ & $62.3(57.31-67.19)$ \\
TURP* & $5,704(26.61)$ & $64.5(61.5-67.5)$ & $61.58(57.07-66.31)$ \\
Non-TURP* & $15,833(73.39)$ & $63.5(59.5-66.5)$ & $62.57(57.4-67.41)$ \\
PCa & & & \\
Any PCa & $14,311(6.67)$ & $63.5(59.5-66.5)$ & $65.35(60.08-69.16)$ \\
Lethal PCa & $692(4.84)$ & $65.5(62.5-68.5)$ & $65.5(61.02-69.46)$ \\
Non-lethal PCa & $13,619(95.16)$ & $63.5(59.5-66.5)$ & $65.33(60.8-69.12)$ \\
Both BPH and PCa & $3,231(1.5)$ & $64.5(61.5-67.5)$ & $62.57(58.06-67.12)^{* *}$ \\
Neither BPH or PCa & $179,014(83.37)$ & $57.5(49.5-63.5)$ & $\backslash$ \\
\hline N & &
\end{tabular}

*Number of subjects with missing data for TURP $(49,817)$

**Based on earlier age at diagnosis of $\mathrm{BPH}$ and $\mathrm{PCa}$ 
Table 2. Performance of GRS for predicting disease risk in the UK Biobank, $N=214,717$

\begin{tabular}{lllll}
\hline & & & \multicolumn{2}{c}{ Association test* } \\
\cline { 3 - 5 } GRS (No. risk SNPs) & Comparison & Sample size & OR (95\% Cl) & $\mathrm{P}$ \\
\hline BPH (15 SNPs) & BPH vs. controls & 24,623 vs 190,094 & $2.39(2.26-2.52)$ & $5.23 \mathrm{E}-211$ \\
& BPH-TURP vs. controls & 5,704 vs 205,927 & $3.61(3.26-3.98)$ & $3.76 \mathrm{E}-140$ \\
& BPH-TURP vs. BPH non-TURP & 5,704 vs 15,833 & $2.01(1.78-2.26)$ & $9.65 \mathrm{E}-31$ \\
& PCa vs. controls & 14,311 vs 200,406 & $1.26(1.18-1.36)$ & $1.62 \mathrm{E}-10$ \\
& Lethal PCa vs. controls & 692 vs 214,025 & $0.74(0.53-1.02)$ & 0.07 \\
PCa (239 SNPs) & Lethal PCa vs. non-lethal PCa & 692 vs 13,619 & $0.58(0.41-0.81)$ & $1.57 \mathrm{E}-03$ \\
& BPH vs. controls & 24,623 vs 190,094 & $1.03(1.02-1.04)$ & $8.57 \mathrm{E}-06$ \\
& BPH-TURP vs. controls & 5,704 vs 205,927 & $1.04(1.02-1.07)$ & $1.02 \mathrm{E}-03$ \\
& BPH-TURP vs. BPH non-TURP & 5,704 vs 15,833 & $1.02(0.99-1.06)$ & 0.13 \\
& PCa vs. controls & 14,311 vs 200,406 & $1.53(1.51-1.55)$ & $<1 \mathrm{E}-299$ \\
& Lethal PCa vs. controls & 692 vs 214,025 & $1.25(1.21-1.29)$ & $2.74 \mathrm{E}-34$ \\
& Lethal PCa vs. non-lethal PCa & 692 vs 13,619 & $0.99(0.94-1.04)$ & 0.79 \\
\hline
\end{tabular}

*Adjusting for age at recruitment and genetic background (top 10 principal components) 


\begin{tabular}{|c|c|c|c|c|c|c|c|c|c|c|c|c|}
\hline & & & & & & orted from published GWAS & & Associat & ion with $\mathrm{BPH}$ in $\mathrm{U}$ & & & Associat \\
\hline & & & & & & & & $\mathrm{AF}$ & & & & $\mathrm{AF}$ \\
\hline SNP & $\mathrm{CHR}$ & POS & RA & RAF & OR & Reference & Cases & Controls & OR $(95 \% \mathrm{Cl})$ & $\mathrm{P}$ & Cases & Controls \\
\hline BPH & & & & & & & & & & & & \\
\hline rs 2556378 & 2 & $60,762,502$ & T & 0.16 & 1.12 & Gudmundsson J, Nat Commun. 2018 & 0.17 & 0.16 & $1.13(1.1-1.16)$ & $9.68 \mathrm{E}-22$ & 0.16 & 0.16 \\
\hline rs2853677 & 5 & $1,287,194$ & G & 0.41 & 1.09 & Gudmundsson J, Nat Commun. 2018 & 0.61 & 0.58 & $1.11(1.13-1.09)$ & $1.75 \mathrm{E}-26$ & 0.60 & 0.59 \\
\hline rs381949 & 5 & $1,322,468$ & G & 0.60 & 1.11 & Gudmundsson J, Nat Commun. 2018 & 0.44 & 0.42 & $1.09(1.07-1.11)$ & $2.66 \mathrm{E}-19$ & 0.43 & 0.42 \\
\hline rs10054105 & 5 & $110,909,333$ & $\mathrm{~T}$ & 0.80 & 1.10 & Gudmundsson J, Nat Commun. 2018 & 0.81 & 0.80 & $1.09(1.12-1.07)$ & $4.02 \mathrm{E}-13$ & 0.80 & 0.80 \\
\hline rs677394 & 5 & $134,607,559$ & c & 0.91 & 1.14 & Gudmundsson J, Nat Commun. 2018 & 0.92 & 0.91 & $1.13(1.17-1.1)$ & $4.78 \mathrm{E}-13$ & 0.91 & 0.91 \\
\hline rs200476 & 6 & $27,768,348$ & A & 0.82 & 1.14 & Gudmundsson J, Nat Commun. 2018 & 0.82 & 0.80 & $1.09(1.12-1.06)$ & $9.09 \mathrm{E}-12$ & 0.81 & 0.80 \\
\hline rs148678804 & 10 & $22,427,289$ & A & 0.03 & 1.27 & Gudmundsson J, Nat Commun. 2018 & 0.04 & 0.03 & $1.25(1.19-1.32)$ & 1.23E-18 & 0.03 & 0.03 \\
\hline rs4548546 & 10 & $122,629,579$ & $\mathrm{~T}$ & 0.33 & 1.11 & Gudmundsson J, Nat Commun. 2018 & 0.35 & 0.33 & $1.1(1.08-1.12)$ & $2.25 \mathrm{E}-20$ & 0.34 & 0.33 \\
\hline rs11199879 & 10 & $123,045,212$ & c & 0.24 & 1.14 & Gudmundsson J, Nat Commun. 2018 & 0.25 & 0.22 & $1.15(1.13-1.18)$ & $1.18 \mathrm{E}-36$ & 0.22 & 0.23 \\
\hline rs72878024 & 11 & 199,492 & G & 0.93 & 1.18 & Gudmundsson J, Nat Commun. 2018 & 0.93 & 0.92 & $1.13(1.18-1.09)$ & 4.29E-11 & 0.93 & 0.92 \\
\hline rs 2555019 & 12 & $114,668,618$ & c & 0.52 & 1.08 & Gudmundsson J, Nat Commun. 2018 & 0.55 & 0.53 & $1.05(1.07-1.03)$ & $1.02 \mathrm{E}-06$ & 0.52 & 0.54 \\
\hline rs8853 & 12 & $115,108,907$ & c & 0.48 & 1.07 & Gudmundsson J, Nat Commun. 2018 & 0.50 & 0.49 & $1.04(1.02-1.06)$ & $1.04 \mathrm{E}-04$ & 0.50 & 0.49 \\
\hline rs1638703 & 13 & $51,088,356$ & c & 0.25 & 1.10 & Gudmundsson J, Nat Commun. 2018 & 0.27 & 0.25 & $1.08(1.05-1.1)$ & $5.91 \mathrm{E}-11$ & 0.26 & 0.25 \\
\hline rs11651052 & 17 & $36,102,381$ & G & 0.55 & 1.08 & Gudmundsson J, Nat Commun. 2018 & 0.54 & 0.52 & $1.05(1.07-1.03)$ & $5.32 \mathrm{E}-07$ & 0.57 & 0.52 \\
\hline rs9958656 & 18 & $19,904,144$ & T & 0.42 & 1.11 & Gudmundsson J, Nat Commun. 2018 & 0.43 & 0.41 & $1.08(1.06-1.1)$ & $2.14 \mathrm{E}-15$ & 0.41 & 0.42 \\
\hline PCa & & & & & & & & & & & & \\
\hline rs636291 & 1 & $10,556,097$ & A & 0.69 & 1.18 & Al Olama AA, Nat Genet. 2014 & 0.68 & 0.67 & $1.05(1.07-1.03)$ & $1.11 \mathrm{E}-05$ & 0.68 & 0.67 \\
\hline rs10803412 & 1 & $16,376,831$ & C & 0.18 & 1.05 & DV Conti, Nat Genet. 2021 & 0.18 & 0.18 & $1.02(0.99-1.04)$ & 0.19 & 0.18 & 0.18 \\
\hline rs17599629 & 1 & $150,658,287$ & G & 0.21 & 1.07 & Schumacher FR, Nat Genet. 2018 & 0.23 & 0.23 & $1.01(0.99-1.03)$ & 0.43 & 0.24 & 0.23 \\
\hline rs1811698 & 1 & $150,772,613$ & c & 0.90 & 1.09 & DV Conti, Nat Genet. 2021 & 0.90 & 0.91 & $0.99(1.02-0.95)$ & 0.37 & 0.91 & 0.91 \\
\hline rs10127983 & 1 & $153,923,276$ & $\mathrm{~T}$ & 0.30 & 1.07 & DV Conti, Nat Genet. 2021 & 0.30 & 0.30 & $0.99(0.97-1.01)$ & 0.50 & 0.30 & 0.30 \\
\hline rs1218582 & 1 & $154,834,183$ & G & 0.43 & 1.05 & Schumacher FR, Nat Genet. 2018 & 0.44 & 0.44 & $1.01(0.99-1.03)$ & 0.37 & 0.45 & 0.44 \\
\hline rs147847496 & 1 & $155,118,588$ & c & 0.96 & 1.17 & DV Conti, Nat Genet. 2021 & 0.97 & 0.97 & $1.08(1.14-1.01)$ & 0.02 & 0.98 & 0.97 \\
\hline rs184104770 & 1 & $155,690,186$ & A & 0.02 & 1.17 & DV Conti, Nat Genet. 2021 & 0.02 & 0.02 & $1.05(0.98-1.12)$ & 0.20 & 0.02 & 0.02 \\
\hline rs80237341 & 1 & $157,119,915$ & c & 0.02 & 1.14 & DV Conti, Nat Genet. 2021 & 0.02 & 0.02 & $1(0.93-1.08)$ & 0.97 & 0.02 & 0.02 \\
\hline rs6660538 & 1 & $163,295,678$ & A & 0.36 & 1.03 & DV Conti, Nat Genet. 2021 & 0.38 & 0.38 & $1(0.98-1.02)$ & 0.91 & 0.39 & 0.38 \\
\hline rs4075646 & 1 & $167,135,941$ & $\mathrm{~T}$ & 0.04 & 1.06 & DV Conti, Nat Genet. 2021 & 0.03 & 0.04 & $0.95(0.9-1)$ & 0.07 & 0.04 & 0.04 \\
\hline rs507603 & 1 & $179,897,070$ & A & 0.15 & 1.04 & DV Conti, Nat Genet. 2021 & 0.16 & 0.16 & $0.99(0.96-1.02)$ & 0.42 & 0.17 & 0.16 \\
\hline rs34295433 & 1 & $183,032,447$ & CTAAC & 0.52 & 1.04 & DV Conti, Nat Genet. 2021 & 0.55 & 0.55 & $0.99(1.01-0.97)$ & 0.50 & 0.56 & 0.55 \\
\hline rs4245739 & 1 & $204,518,842$ & A & 0.76 & 1.10 & DV Conti, Nat Genet. 2021 & 0.73 & 0.72 & $1.01(1.03-0.99)$ & 0.34 & 0.74 & 0.72 \\
\hline rs708723 & 1 & $205,739,266$ & c & 0.44 & 1.04 & DV Conti, Nat Genet. 2021 & 0.45 & 0.45 & $1(0.98-1.02)$ & 0.84 & 0.47 & 0.45 \\
\hline rs11686272 & 2 & $8,598,444$ & T & 0.45 & 1.05 & DV Conti, Nat Genet. 2021 & 0.45 & 0.45 & $1.01(0.99-1.03)$ & 0.15 & 0.46 & 0.45 \\
\hline rs11902236 & 2 & $10,117,868$ & T & 0.27 & 1.07 & Eeles RA, Nat Genet. 2013 & 0.28 & 0.28 & $1.03(1.01-1.05)$ & 0.01 & 0.28 & 0.28 \\
\hline rs1990613 & 2 & $10,781,975$ & $\mathrm{~T}$ & 0.49 & 1.07 & DV Conti, Nat Genet. 2021 & 0.52 & 0.52 & $0.99(1.01-0.97)$ & 0.37 & 0.53 & 0.52 \\
\hline rs7602028 & 2 & $16,016,503$ & c & 0.72 & 1.05 & DV Conti, Nat Genet. 2021 & 0.73 & 0.74 & $1(1.02-0.97)$ & 0.64 & 0.74 & 0.73 \\
\hline rs9306894 & 2 & $20,878,105$ & G & 0.38 & 1.08 & DV Conti, Nat Genet. 2021 & 0.36 & 0.36 & $1(0.98-1.02)$ & 0.74 & 0.37 & 0.36 \\
\hline rs6738169 & 2 & $43,064,555$ & C & 0.71 & 1.04 & DV Conti, Nat Genet. 2021 & 0.72 & 0.72 & $1.02(1.04-0.99)$ & 0.15 & 0.73 & 0.72 \\
\hline rs7591218 & 2 & $43,637,998$ & A & 0.32 & 1.07 & DV Conti, Nat Genet. 2021 & 0.30 & 0.30 & $1.01(0.98-1.03)$ & 0.67 & 0.32 & 0.30 \\
\hline rs 28514770 & 2 & $43,851,282$ & c & 0.72 & 1.05 & DV Conti, Nat Genet. 2021 & 0.72 & 0.72 & $1.01(1.03-0.99)$ & 0.57 & 0.73 & 0.72 \\
\hline rs11125927 & 2 & $62,752,975$ & G & 0.11 & 1.07 & DV Conti, Nat Genet. 2021 & 0.11 & 0.11 & $1.01(0.98-1.04)$ & 0.41 & 0.12 & 0.11 \\
\hline rs58235267 & 2 & $63,277,843$ & G & 0.47 & 1.12 & DV Conti, Nat Genet. 2021 & 0.49 & 0.49 & $1.01(0.99-1.03)$ & 0.54 & 0.52 & 0.49 \\
\hline rs139283528 & 2 & $63,938,756$ & G & 0.98 & 1.28 & DV Conti, Nat Genet. 2021 & 0.99 & 0.98 & $1.02(1.11-0.95)$ & 0.58 & 0.99 & 0.98 \\
\hline rs74702681 & 2 & $66,652,885$ & $\mathrm{~T}$ & 0.02 & 1.17 & DV Conti, Nat Genet. 2021 & 0.02 & 0.02 & $1.05(0.98-1.11)$ & 0.17 & 0.03 & 0.02 \\
\hline rs2028900 & 2 & $85,767,735$ & c & 0.57 & 1.09 & DV Conti, Nat Genet. 2021 & 0.54 & 0.55 & $0.98(1-0.96)$ & 0.01 & 0.57 & 0.55 \\
\hline rs2165108 & 2 & $111,861,993$ & A & 0.04 & 1.10 & DV Conti, Nat Genet. 2021 & 0.05 & 0.05 & $1(0.96-1.05)$ & 0.90 & 0.05 & 0.05 \\
\hline rs11691517 & 2 & $111,893,096$ & $\mathrm{~T}$ & 0.75 & 1.06 & DV Conti, Nat Genet. 2021 & 0.75 & 0.75 & $1(1.03-0.98)$ & 0.78 & 0.76 & 0.75 \\
\hline rs111595856 & 2 & $121,103,598$ & $\mathrm{~T}$ & 0.06 & 1.09 & DV Conti, Nat Genet. 2021 & 0.06 & 0.06 & $1.02(0.98-1.07)$ & 0.24 & 0.07 & 0.06 \\
\hline rs10206072 & 2 & $121,373,466$ & G & 0.90 & 1.05 & DV Conti, Nat Genet. 2021 & 0.90 & 0.90 & $1.01(1.04-0.98)$ & 0.66 & 0.90 & 0.90 \\
\hline rs16854905 & 2 & $169,012,955$ & c & 0.90 & 1.06 & DV Conti, Nat Genet. 2021 & 0.91 & 0.91 & $1.03(1.06-0.99)$ & 0.12 & 0.91 & 0.91 \\
\hline rs77167534 & 2 & $173,319,930$ & c & 0.94 & 1.27 & DV Conti, Nat Genet. 2021 & 0.94 & 0.94 & $1.02(1.06-0.98)$ & 0.26 & 0.95 & 0.94 \\
\hline rs34925593 & 2 & $174,234,547$ & c & 0.50 & 1.05 & DV Conti, Nat Genet. 2021 & 0.48 & 0.48 & $1(0.98-1.02)$ & 0.80 & 0.49 & 0.48 \\
\hline rs1861270 & 2 & $202,126,615$ & G & 0.75 & 1.05 & DV Conti, Nat Genet. 2021 & 0.75 & 0.75 & $1(1.02-0.97)$ & 0.76 & 0.76 & 0.75 \\
\hline rs12621900 & 2 & $208,118,301$ & c & 0.78 & 1.05 & DV Conti, Nat Genet. 2021 & 0.78 & 0.78 & $0.99(1.01-0.97)$ & 0.33 & 0.78 & 0.78 \\
\hline rs74001374 & 2 & $238,411,293$ & c & 0.99 & 1.13 & DV Conti, Nat Genet. 2021 & 0.99 & 0.99 & $1(1.14-0.88)$ & 0.97 & 0.99 & 0.99 \\
\hline rs2292884 & 2 & $238,443,226$ & G & 0.23 & 1.06 & DV Conti, Nat Genet. 2021 & 0.26 & 0.26 & $1(0.98-1.02)$ & 1.00 & 0.27 & 0.25 \\
\hline rs77559646 & 2 & $242,135,265$ & A & 0.03 & 1.33 & DV Conti, Nat Genet. 2021 & 0.02 & 0.02 & $0.95(0.89-1.02)$ & 0.17 & 0.02 & 0.02 \\
\hline rs2074840 & 2 & $242,141,719$ & c & 0.31 & 1.05 & DV Conti, Nat Genet. 2021 & 0.30 & 0.30 & $1(0.98-1.02)$ & 0.92 & 0.31 & 0.30 \\
\hline rs76832527 & 2 & $242,157,241$ & A & 0.17 & 1.12 & DV Conti, Nat Genet. 2021 & 0.18 & 0.18 & $0.96(0.93-0.98)$ & $1.22 \mathrm{E}-03$ & 0.19 & 0.18 \\
\hline rs6550597 & 3 & $18,738,940$ & A & 0.73 & 1.03 & DV Conti, Nat Genet. 2021 & 0.73 & 0.73 & $0.99(1.01-0.97)$ & $3.22 \mathrm{E}-01$ & 0.74 & 0.73 \\
\hline rs7618603 & 3 & $23,153,062$ & A & 0.17 & 1.06 & DV Conti, Nat Genet. 2021 & 0.17 & 0.17 & $1(0.97-1.02)$ & $9.31 \mathrm{E}-01$ & 0.18 & 0.17 \\
\hline rs2660753 & 3 & $87,110,674$ & T & 0.12 & 1.13 & Schumacher FR, Nat Genet. 2018 & 0.10 & 0.10 & $1.02(0.99-1.06)$ & $1.61 \mathrm{E}-01$ & 0.11 & 0.10 \\
\hline rs7628934 & 3 & $87,175,984$ & C & 0.52 & 1.10 & DV Conti, Nat Genet. 2021 & 0.50 & 0.50 & $1(0.98-1.02)$ & $7.71 \mathrm{E}-01$ & 0.52 & 0.50 \\
\hline rs114810266 & 3 & $87,399,362$ & A & 0.98 & 1.17 & DV Conti, Nat Genet. 2021 & 0.98 & 0.98 & $0.96(1.02-0.9)$ & $2.03 \mathrm{E}-01$ & 0.98 & 0.98 \\
\hline rs1283104 & 3 & $106,962,521$ & G & 0.37 & 1.05 & DV Conti, Nat Genet. 2021 & 0.37 & 0.37 & $0.99(0.97-1.01)$ & 2.93E-01 & 0.38 & 0.37 \\
\hline rs151038334 & 3 & $107,193,337$ & c & 0.92 & 1.08 & DV Conti, Nat Genet. 2021 & 0.92 & 0.92 & $1(1.04-0.97)$ & $7.89 \mathrm{E}-01$ & 0.93 & 0.92 \\
\hline rs7611694 & 3 & $113,275,624$ & A & 0.57 & 1.09 & Schumacher FR, Nat Genet. 2018 & 0.60 & 0.60 & $0.99(1.01-0.97)$ & $2.00 \mathrm{E}-01$ & 0.61 & 0.60 \\
\hline rs2811476 & 3 & $127,898,501$ & c & 0.27 & 1.11 & DV Conti, Nat Genet. 2021 & 0.27 & 0.26 & $1.03(1.01-1.05)$ & $1.37 \mathrm{E}-02$ & 0.28 & 0.26 \\
\hline rs35006112 & 3 & $128,213,994$ & G & 0.85 & 1.07 & DV Conti, Nat Genet. 2021 & 0.86 & 0.85 & $1.02(1.05-0.99)$ & $1.68 \mathrm{E}-01$ & 0.86 & 0.85 \\
\hline rs1457063 & 3 & $137,562,823$ & A & 0.62 & 1.04 & DV Conti, Nat Genet. 2021 & 0.63 & 0.62 & $1.02(1.04-1)$ & 7.73E-02 & 0.63 & 0.62 \\
\hline rs7650602 & 3 & $141,147,414$ & c & 0.43 & 1.05 & DV Conti, Nat Genet. 2021 & 0.46 & 0.45 & $1.06(1.04-1.08)$ & $3.27 \mathrm{E}-08$ & 0.46 & 0.45 \\
\hline rs182314334 & 3 & $152,004,202$ & $\mathrm{~T}$ & 0.98 & 1.09 & Schumacher FR, Nat Genet. 2018 & 0.90 & 0.90 & $0.97(1-0.94)$ & $6.35 \mathrm{E}-02$ & 0.90 & 0.90 \\
\hline rs142436749 & 3 & $169,093,100$ & G & 0.01 & 1.25 & Schumacher FR, Nat Genet. 2018 & 0.01 & 0.01 & $1.03(0.95-1.12)$ & $4.52 \mathrm{E}-01$ & 0.01 & 0.01 \\
\hline rs2293607 & 3 & $169,482,335$ & $\mathrm{~T}$ & 0.75 & 1.06 & DV Conti, Nat Genet. 2021 & 0.76 & 0.75 & $1.03(1.05-1.01)$ & $1.28 \mathrm{E}-02$ & 0.76 & 0.75 \\
\hline rs78416326 & 3 & $170,074,517$ & G & 0.80 & 1.21 & DV Conti, Nat Genet. 2021 & 0.80 & 0.80 & $0.99(1.02-0.97)$ & 4.63E-01 & 0.82 & 0.80 \\
\hline rs10936632 & 3 & $170,130,102$ & A & 0.52 & 1.10 & Schumacher FR, Nat Genet. 2018 & 0.52 & 0.52 & $0.99(1.01-0.97)$ & $2.73 \mathrm{E}-01$ & 0.54 & 0.52 \\
\hline rs10009409 & 4 & $73,855,253$ & T & 0.31 & 1.06 & Schumacher FR, Nat Genet. 2018 & 0.29 & 0.29 & $1.01(0.98-1.03)$ & $6.61 \mathrm{E}-01$ & 0.30 & 0.29 \\
\hline rs17804499 & 4 & $74,442,349$ & G & 0.95 & 1.23 & DV Conti, Nat Genet. 2021 & 0.94 & 0.94 & $0.98(1.02-0.95)$ & 4.34E-01 & 0.95 & 0.94 \\
\hline rs13142786 & 4 & $74,477,135$ & $\mathrm{~T}$ & 0.50 & 1.08 & DV Conti, Nat Genet. 2021 & 0.49 & 0.49 & $1.01(0.99-1.03)$ & $2.86 \mathrm{E}-01$ & 0.49 & 0.49 \\
\hline rs17021918 & 4 & $95,562,877$ & c & 0.65 & 1.09 & Schumacher FR, Nat Genet. 2018 & 0.65 & 0.65 & $1(1.02-0.98)$ & $9.69 \mathrm{E}-01$ & 0.67 & 0.65 \\
\hline rs7679673 & 4 & $106,061,534$ & c & 0.58 & 1.11 & DV Conti, Nat Genet. 2021 & 0.63 & 0.62 & $1.01(1.03-0.99)$ & 3.87E-01 & 0.65 & 0.62 \\
\hline rs77821238 & 4 & $140,948,835$ & c & 0.83 & 1.05 & DV Conti, Nat Genet. 2021 & 0.83 & 0.83 & $1.02(1.04-0.99)$ & $2.01 \mathrm{E}-01$ & 0.83 & 0.83 \\
\hline rs72725734 & 4 & $146,879,237$ & G & 0.15 & 1.04 & DV Conti, Nat Genet. 2021 & 0.15 & 0.14 & $1.02(0.99-1.05)$ & $1.73 \mathrm{E}-01$ & 0.15 & 0.14 \\
\hline
\end{tabular}


It is made available under a CC-BY-NC 4.0 International license

\begin{tabular}{|c|c|c|c|c|c|c|c|c|c|c|c|}
\hline rs147762399 & 4 & $152,030,340$ & $\mathrm{~T}$ & 0.03 & 1.10 & DV Conti, Nat Genet. 2021 & 0.04 & 0.04 & $0.97(0.92-1.02)$ & 2.15E-01 & 0.04 \\
\hline rs2242652 & 5 & $1,280,028$ & G & 0.80 & 1.14 & DV Conti, Nat Genet. 2021 & 0.81 & 0.81 & $1(1.02-0.98)$ & 9.96E-01 & 0.83 \\
\hline rs71595003 & 5 & $1,292,118$ & A & 0.03 & 1.19 & DV Conti, Nat Genet. 2021 & 0.03 & 0.03 & $0.95(0.89-1)$ & $6.09 \mathrm{E}-02$ & 0.03 \\
\hline rs2736098 & 5 & $1,294,086$ & $\mathrm{~T}$ & 0.26 & 1.08 & DV Conti, Nat Genet. 2021 & 0.29 & 0.28 & $1.08(1.06-1.11)$ & $2.90 \mathrm{E}-13$ & 0.30 \\
\hline rs4975758 & 5 & $1,891,174$ & G & 0.49 & 1.08 & DV Conti, Nat Genet. 2021 & 0.47 & 0.46 & $1.02(1-1.04)$ & $6.14 \mathrm{E}-02$ & 0.49 \\
\hline rs10941370 & 5 & $37,833,419$ & $\mathrm{~T}$ & 0.44 & 1.03 & DV Conti, Nat Genet. 2021 & 0.45 & 0.45 & $1(0.98-1.02)$ & $6.90 \mathrm{E}-01$ & 0.46 \\
\hline rs2121875 & 5 & $44,365,545$ & c & 0.32 & 1.05 & Schumacher FR, Nat Genet. 2018 & 0.33 & 0.33 & $0.99(0.97-1.02)$ & $5.98 \mathrm{E}-01$ & 0.34 \\
\hline rs9292122 & 5 & $56,087,910$ & A & 0.69 & 1.04 & DV Conti, Nat Genet. 2021 & 0.73 & 0.73 & $1.01(1.03-0.98)$ & 5.97E-01 & 0.73 \\
\hline rs10793821 & 5 & $133,836,209$ & $\mathrm{~T}$ & 0.57 & 1.06 & DV Conti, Nat Genet. 2021 & 0.57 & 0.56 & $1.01(1.03-0.99)$ & 3.64E-01 & 0.58 \\
\hline rs9686557 & 5 & $172,959,030$ & c & 0.44 & 1.05 & DV Conti, Nat Genet. 2021 & 0.45 & 0.45 & $1(0.99-1.02)$ & $6.59 \mathrm{E}-01$ & 0.46 \\
\hline rs61739424 & 5 & $177,683,905$ & G & 0.96 & 1.10 & DV Conti, Nat Genet. 2021 & 0.96 & 0.95 & $1.02(1.07-0.97)$ & 4.54E-01 & 0.96 \\
\hline rs2672843 & 5 & $177,891,551$ & G & 0.40 & 1.05 & DV Conti, Nat Genet. 2021 & 0.41 & 0.41 & $1.01(0.99-1.03)$ & 6.19E-01 & 0.41 \\
\hline rs4976790 & 5 & $177,968,915$ & $\mathrm{~T}$ & 0.11 & 1.08 & Schumacher FR, Nat Genet. 2018 & 0.12 & 0.11 & $1.03(1-1.06)$ & 4.99E-02 & 0.12 \\
\hline rs2814811 & 6 & $1,670,985$ & A & 0.39 & 1.04 & DV Conti, Nat Genet. 2021 & 0.41 & 0.41 & $1(0.98-1.02)$ & 7.95E-01 & 0.42 \\
\hline rs2018336 & 6 & $11,217,897$ & $\mathrm{~T}$ & 0.79 & 1.07 & DV Conti, Nat Genet. 2021 & 0.77 & 0.77 & $1(1.03-0.98)$ & $7.82 \mathrm{E}-01$ & 0.78 \\
\hline rs6927369 & 6 & $21,330,689$ & c & 0.81 & 1.05 & DV Conti, Nat Genet. 2021 & 0.80 & 0.81 & $0.99(1.01-0.97)$ & $3.59 \mathrm{E}-01$ & 0.81 \\
\hline rs12665509 & 6 & $21,878,849$ & A & 0.45 & 1.04 & DV Conti, Nat Genet. 2021 & 0.45 & 0.45 & $1(0.98-1.02)$ & $8.32 \mathrm{E}-01$ & 0.46 \\
\hline rs7767188 & 6 & $30,073,776$ & A & 0.21 & 1.06 & Schumacher FR, Nat Genet. 2018 & 0.20 & 0.19 & $1.01(0.98-1.03)$ & $6.64 \mathrm{E}-01$ & 0.20 \\
\hline rs130067 & 6 & $31,118,511$ & G & 0.20 & 1.05 & Kote-Jarai Z, Nat Genet. 2011 & 0.20 & 0.20 & $1.03(1-1.05)$ & $2.00 \mathrm{E}-02$ & 0.21 \\
\hline rs3129859 & 6 & $32,400,939$ & G & 0.68 & 1.06 & Schumacher FR, Nat Genet. 2018 & 0.68 & 0.68 & $1.03(1.05-1.01)$ & $3.59 \mathrm{E}-03$ & 0.69 \\
\hline rs9296068 & 6 & $32,988,695$ & $\mathrm{~T}$ & 0.65 & 1.05 & Schumacher FR, Nat Genet. 2018 & 0.68 & 0.68 & $1(1.02-0.98)$ & 7.70E-01 & 0.68 \\
\hline rs9469899 & 6 & $34,793,124$ & A & 0.37 & 1.05 & DV Conti, Nat Genet. 2021 & 0.36 & 0.36 & $1.01(0.99-1.03)$ & 3.05E-01 & 0.37 \\
\hline rs4711748 & 6 & $43,694,598$ & $\mathrm{~T}$ & 0.22 & 1.05 & Schumacher FR, Nat Genet. 2018 & 0.23 & 0.23 & $1.01(0.98-1.03)$ & 5.19E-01 & 0.23 \\
\hline rs9472120 & 6 & $43,709,785$ & c & 0.50 & 1.04 & DV Conti, Nat Genet. 2021 & 0.48 & 0.47 & $1.02(1.01-1.04)$ & $1.50 \mathrm{E}-02$ & 0.49 \\
\hline rs9443189 & 6 & $76,495,882$ & A & 0.87 & 1.07 & DV Conti, Nat Genet. 2021 & 0.86 & 0.86 & $1(1.03-0.97)$ & 9.39E-01 & 0.86 \\
\hline rs2038542 & 6 & $109,295,293$ & c & 0.15 & 1.08 & DV Conti, Nat Genet. 2021 & 0.14 & 0.14 & $0.98(0.96-1.01)$ & 1.97E-01 & 0.15 \\
\hline rs339331 & 6 & $117,210,052$ & $\mathrm{~T}$ & 0.68 & 1.09 & Schumacher FR, Nat Genet. 2018 & 0.70 & 0.69 & $1.04(1.06-1.01)$ & 1.03E-03 & 0.72 \\
\hline rs13215045 & 6 & $153,447,516$ & c & 0.67 & 1.08 & DV Conti, Nat Genet. 2021 & 0.70 & 0.70 & $1.02(1.04-1)$ & $9.18 \mathrm{E}-02$ & 0.71 \\
\hline rs963800 & 6 & $160,150,279$ & c & 0.79 & 1.06 & DV Conti, Nat Genet. 2021 & 0.78 & 0.78 & $1(1.03-0.98)$ & 7.53E-01 & 0.79 \\
\hline rs9364554 & 6 & $160,833,664$ & $\mathrm{~T}$ & 0.27 & 1.11 & Schumacher FR, Nat Genet. 2018 & 0.30 & 0.30 & $0.99(0.97-1.01)$ & $1.67 \mathrm{E}-01$ & 0.32 \\
\hline rs138004030 & 6 & $170,475,879$ & G & 0.94 & 1.27 & Schumacher FR, Nat Genet. 2018 & 0.93 & 0.93 & $0.99(1.02-0.95)$ & 4.55E-01 & 0.93 \\
\hline rs4513875 & 7 & $1,928,159$ & $\mathrm{~T}$ & 0.38 & 1.04 & DV Conti, Nat Genet. 2021 & 0.40 & 0.40 & $1(0.98-1.02)$ & $9.23 \mathrm{E}-01$ & 0.41 \\
\hline rs35389879 & 7 & $21,812,043$ & $\mathrm{~T}$ & 0.43 & 1.04 & DV Conti, Nat Genet. 2021 & 0.42 & 0.41 & $1.03(1.01-1.05)$ & $9.90 \mathrm{E}-03$ & 0.41 \\
\hline rs10486567 & 7 & $27,976,563$ & G & 0.77 & 1.12 & DV Conti, Nat Genet. 2021 & 0.77 & 0.77 & $1.02(1.04-1)$ & $1.08 \mathrm{E}-01$ & 0.79 \\
\hline rs17621345 & 7 & $40,875,192$ & A & 0.74 & 1.07 & Schumacher FR, Nat Genet. 2018 & 0.75 & 0.75 & $1.03(1.05-1)$ & $2.81 \mathrm{E}-02$ & 0.76 \\
\hline rs834608 & 7 & $47,451,918$ & A & 0.60 & 1.05 & DV Conti, Nat Genet. 2021 & 0.58 & 0.58 & $1(1.02-0.98)$ & $9.41 \mathrm{E}-01$ & 0.59 \\
\hline rs6955627 & 7 & $92,577,760$ & C & 0.90 & 1.05 & DV Conti, Nat Genet. 2021 & 0.92 & 0.92 & $0.95(0.98-0.91)$ & $1.83 \mathrm{E}-03$ & 0.93 \\
\hline rs6465657 & 7 & $97,816,327$ & c & 0.48 & 1.11 & Schumacher FR, Nat Genet. 2018 & 0.46 & 0.47 & $0.99(0.97-1.01)$ & $4.25 \mathrm{E}-01$ & 0.49 \\
\hline rs870167 & 8 & $8,498,803$ & G & 0.06 & 1.06 & DV Conti, Nat Genet. 2021 & 0.07 & 0.07 & $1.01(0.97-1.05)$ & $6.38 \mathrm{E}-01$ & 0.08 \\
\hline rs2928679 & 8 & $23,438,975$ & A & 0.43 & 1.05 & Schumacher FR, Nat Genet. 2018 & 0.48 & 0.47 & $1.05(1.03-1.07)$ & 2.64E-06 & 0.48 \\
\hline rs1160267 & 8 & $23,529,521$ & G & 0.43 & 1.15 & DV Conti, Nat Genet. 2021 & 0.43 & 0.42 & $1.03(1.02-1.05)$ & 5.99E-04 & 0.45 \\
\hline rs11135910 & 8 & $25,892,142$ & $\mathrm{~T}$ & 0.15 & 1.08 & Schumacher FR, Nat Genet. 2018 & 0.17 & 0.17 & $1.02(1-1.05)$ & 7.11E-02 & 0.18 \\
\hline rs12677206 & 8 & $26,063,165$ & A & 0.33 & 1.04 & DV Conti, Nat Genet. 2021 & 0.33 & 0.34 & $0.98(0.96-1)$ & $9.22 \mathrm{E}-02$ & 0.34 \\
\hline rs11467 & 8 & $38,644,914$ & A & 0.62 & 1.04 & DV Conti, Nat Genet. 2021 & 0.62 & 0.62 & $1(1.02-0.98)$ & $7.22 \mathrm{E}-01$ & 0.62 \\
\hline rs73700335 & 8 & $108,923,107$ & G & 0.85 & 1.05 & DV Conti, Nat Genet. 2021 & 0.84 & 0.84 & $0.99(1.02-0.97)$ & $4.58 \mathrm{E}-01$ & 0.85 \\
\hline rs12543663 & 8 & $127,924,659$ & c & 0.31 & 1.12 & Schumacher FR, Nat Genet. 2018 & 0.31 & 0.31 & $0.99(0.97-1.01)$ & $1.71 \mathrm{E}-01$ & 0.33 \\
\hline rs7463326 & 8 & $128,027,954$ & G & 0.76 & 1.17 & DV Conti, Nat Genet. 2021 & 0.75 & 0.76 & $0.99(1.01-0.97)$ & $2.68 \mathrm{E}-01$ & 0.78 \\
\hline rs77541621 & 8 & $128,077,146$ & A & 0.02 & 1.89 & DV Conti, Nat Genet. 2021 & 0.02 & 0.02 & $0.97(0.91-1.03)$ & 3.43E-01 & 0.04 \\
\hline rs1016343 & 8 & $128,093,297$ & $\mathrm{~T}$ & 0.21 & 1.25 & Hoffmann TJ, Cancer Discov. 2015 & 0.21 & 0.20 & $1.03(1.01-1.06)$ & 4.87E-03 & 0.24 \\
\hline rs13252298 & 8 & $128,095,156$ & A & 0.70 & 1.19 & Al Olama AA, Nat Genet. 2009 & 0.71 & 0.71 & $1(1.02-0.98)$ & $8.71 \mathrm{E}-01$ & 0.74 \\
\hline rs78809737 & 8 & $128,104,218$ & G & 0.96 & 1.08 & DV Conti, Nat Genet. 2021 & 0.96 & 0.95 & $1.04(1.09-0.99)$ & $1.08 \mathrm{E}-01$ & 0.96 \\
\hline rs16902094 & 8 & $128,320,346$ & G & 0.16 & 1.21 & Gudmundsson J, Nat Genet. 2009 & 0.14 & 0.14 & $1.02(1-1.05)$ & 1.10E-01 & 0.16 \\
\hline rs620861 & 8 & $128,335,673$ & G & 0.64 & 1.15 & Schumacher FR, Nat Genet. 2018 & 0.64 & 0.63 & $1.03(1.05-1.01)$ & $8.58 \mathrm{E}-04$ & 0.66 \\
\hline rs6983267 & 8 & $128,413,305$ & G & 0.51 & 1.18 & DV Conti, Nat Genet. 2021 & 0.53 & 0.52 & $1.07(1.09-1.05)$ & $1.31 \mathrm{E}-11$ & 0.57 \\
\hline rs11986220 & 8 & $128,531,689$ & A & 0.11 & 1.56 & Hoffmann TJ, Cancer Discov. 2015 & 0.10 & 0.10 & $0.96(0.93-0.99)$ & $1.01 \mathrm{E}-02$ & 0.13 \\
\hline rs34265760 & 8 & $128,535,543$ & $\mathrm{~T}$ & 0.98 & 1.08 & DV Conti, Nat Genet. 2021 & 0.98 & 0.98 & $1(1.07-0.93)$ & $9.85 \mathrm{E}-01$ & 0.98 \\
\hline rs12549761 & 8 & $128,540,776$ & c & 0.89 & 1.20 & DV Conti, Nat Genet. 2021 & 0.88 & 0.88 & $1(1.03-0.97)$ & $9.38 \mathrm{E}-01$ & 0.90 \\
\hline rs34540271 & 9 & $18,554,773$ & c & 0.70 & 1.05 & DV Conti, Nat Genet. 2021 & 0.69 & 0.70 & $0.98(1-0.96)$ & $8.28 \mathrm{E}-02$ & 0.70 \\
\hline rs1048169 & 9 & $19,055,965$ & c & 0.38 & 1.06 & Schumacher FR, Nat Genet. 2018 & 0.39 & 0.39 & $1(0.98-1.02)$ & $6.45 \mathrm{E}-01$ & 0.40 \\
\hline rs17694493 & 9 & $22,041,998$ & G & 0.14 & 1.08 & DV Conti, Nat Genet. 2021 & 0.13 & 0.13 & $0.97(0.95-1)$ & $5.26 \mathrm{E}-02$ & 0.14 \\
\hline rs10122495 & 9 & $34,049,779$ & $\mathrm{~T}$ & 0.32 & 1.06 & DV Conti, Nat Genet. 2021 & 0.28 & 0.28 & $0.99(0.97-1.02)$ & $5.51 \mathrm{E}-01$ & 0.29 \\
\hline rs4451364 & 9 & $109,532,734$ & A & 0.78 & 1.05 & DV Conti, Nat Genet. 2021 & 0.75 & 0.74 & $1.04(1.07-1.02)$ & 1.69E-04 & 0.75 \\
\hline rs817872 & 9 & $110,144,887$ & c & 0.28 & 1.07 & DV Conti, Nat Genet. 2021 & 0.29 & 0.29 & $1.01(0.99-1.03)$ & 4.06E-01 & 0.30 \\
\hline rs143655302 & 9 & $110,290,217$ & G & 0.98 & 1.30 & DV Conti, Nat Genet. 2021 & 0.98 & 0.98 & $0.97(1.04-0.91)$ & 4.32E-01 & 0.98 \\
\hline rs2241167 & 9 & $130,430,116$ & A & 0.51 & 1.04 & DV Conti, Nat Genet. 2021 & 0.54 & 0.55 & $1(1.01-0.98)$ & 6.03E-01 & 0.55 \\
\hline rs12634 & 9 & $132,573,536$ & $\mathrm{~T}$ & 0.23 & 1.06 & DV Conti, Nat Genet. 2021 & 0.24 & 0.24 & $1.02(0.99-1.04)$ & $1.96 \mathrm{E}-01$ & 0.25 \\
\hline rs141536087 & 10 & 854,691 & GCGC & 0.27 & 1.08 & Schumacher FR, Nat Genet. 2018 & 0.16 & 0.16 & $1.01(0.98-1.03)$ & $6.14 \mathrm{E}-01$ & 0.17 \\
\hline rs7075427 & 10 & $46,104,943$ & A & 0.91 & 1.13 & DV Conti, Nat Genet. 2021 & 0.91 & 0.91 & $0.99(1.02-0.95)$ & $3.79 \mathrm{E}-01$ & 0.92 \\
\hline rs11599847 & 10 & $47,599,029$ & $\mathrm{~T}$ & 0.95 & 1.12 & DV Conti, Nat Genet. 2021 & 0.96 & 0.96 & $1.01(1.06-0.96)$ & 7.30E-01 & 0.96 \\
\hline rs10993994 & 10 & $51,549,496$ & $\mathrm{~T}$ & 0.37 & 1.23 & DV Conti, Nat Genet. 2021 & 0.39 & 0.39 & $1(0.98-1.02)$ & $8.51 \mathrm{E}-01$ & 0.44 \\
\hline rs11817544 & 10 & $80,236,999$ & c & 0.93 & 1.07 & DV Conti, Nat Genet. 2021 & 0.94 & 0.95 & $0.99(1.03-0.95)$ & 5.57E-01 & 0.95 \\
\hline rs12412705 & 10 & $80,835,998$ & c & 0.07 & 1.04 & DV Conti, Nat Genet. 2021 & 0.06 & 0.06 & $0.99(0.95-1.03)$ & $5.73 \mathrm{E}-01$ & 0.06 \\
\hline rs1935581 & 10 & $90,195,149$ & c & 0.62 & 1.05 & DV Conti, Nat Genet. 2021 & 0.64 & 0.64 & $1(1.02-0.98)$ & $8.80 \mathrm{E}-01$ & 0.65 \\
\hline rs3850699 & 10 & $104,414,221$ & A & 0.68 & 1.07 & Schumacher FR, Nat Genet. 2018 & 0.71 & 0.71 & $1.01(1.03-0.99)$ & 4.59E-01 & 0.72 \\
\hline rs10885396 & 10 & $114,711,755$ & $\mathrm{~T}$ & 0.55 & 1.05 & DV Conti, Nat Genet. 2021 & 0.54 & 0.54 & $1(1.02-0.99)$ & $6.29 \mathrm{E}-01$ & 0.55 \\
\hline rs4558107 & 10 & $122,794,926$ & A & 0.38 & 1.06 & DV Conti, Nat Genet. 2021 & 0.39 & 0.39 & $1.01(0.99-1.03)$ & 3.95E-01 & 0.41 \\
\hline rs10788167 & 10 & $123,054,018$ & $\mathrm{~T}$ & 0.76 & 1.06 & DV Conti, Nat Genet. 2021 & 0.75 & 0.78 & $0.87(0.89-0.85)$ & $5.12 \mathrm{E}-36$ & 0.78 \\
\hline rs10749415 & 10 & $123,185,303$ & A & 0.95 & 1.10 & DV Conti, Nat Genet. 2021 & 0.95 & 0.95 & $1.12(1.17-1.07)$ & $2.35 \mathrm{E}-07$ & 0.95 \\
\hline rs4962416 & 10 & $126,696,872$ & c & 0.27 & 1.06 & Schumacher FR, Nat Genet. 2018 & 0.29 & 0.29 & $1(0.98-1.02)$ & 9.87E-01 & 0.30 \\
\hline rs1881502 & 11 & $1,507,512$ & $\mathrm{~T}$ & 0.20 & 1.06 & DV Conti, Nat Genet. 2021 & 0.19 & 0.19 & $0.99(0.96-1.01)$ & 3.13E-01 & 0.20 \\
\hline rs7127900 & 11 & $2,233,574$ & A & 0.20 & 1.19 & Schumacher FR, Nat Genet. 2018 & 0.19 & 0.19 & $1.01(0.98-1.03)$ & $5.32 \mathrm{E}-01$ & 0.22 \\
\hline rs61890184 & 11 & $7,547,587$ & A & 0.12 & 1.08 & DV Conti, Nat Genet. 2021 & 0.12 & 0.12 & $0.98(0.95-1.01)$ & $2.01 \mathrm{E}-01$ & 0.13 \\
\hline rs2277283 & 11 & $61,908,440$ & c & 0.32 & 1.06 & DV Conti, Nat Genet. 2021 & 0.31 & 0.31 & $1(0.98-1.02)$ & $9.45 \mathrm{E}-01$ & 0.33 \\
\hline rs12785905 & 11 & $66,951,965$ & c & 0.04 & 1.12 & DV Conti, Nat Genet. 2021 & 0.06 & 0.05 & $1.05(1.01-1.09)$ & $2.06 \mathrm{E}-02$ & 0.06 \\
\hline rs3018690 & 11 & $68,882,926$ & $\mathrm{~T}$ & 0.46 & 1.05 & DV Conti, Nat Genet. 2021 & 0.43 & 0.43 & $1.01(0.99-1.03)$ & $3.05 \mathrm{E}-01$ & 0.46 \\
\hline rs10896449 & 11 & $68,994,667$ & G & 0.48 & 1.19 & Thomas G, Nat Genet. 2008 & 0.51 & 0.51 & $1.01(1.03-0.99)$ & $5.08 \mathrm{E}-01$ & 0.54 \\
\hline rs3918298 & 11 & $69,463,273$ & A & 0.03 & 1.18 & DV Conti, Nat Genet. 2021 & 0.03 & 0.03 & $1.01(0.95-1.07)$ & 7.73E-01 & 0.03 \\
\hline
\end{tabular}


It is made available under a CC-BY-NC 4.0 International license

\begin{tabular}{|c|c|c|c|c|c|c|c|c|c|c|}
\hline rs56159348 & 11 & $76,267,331$ & $\mathrm{~T}$ & 0.69 & 1.06 & DV Conti, Nat Genet. 2021 & 0.68 & 0.68 & $1(1.02-0.98)$ & 8.22E-01 \\
\hline rs11568818 & 11 & $102,401,661$ & $\mathrm{~T}$ & 0.57 & 1.07 & DV Conti, Nat Genet. 2021 & 0.54 & 0.55 & $0.99(1.01-0.97)$ & $1.55 \mathrm{E}-01$ \\
\hline rs1800057 & 11 & $108,143,456$ & G & 0.02 & 1.16 & Schumacher FR, Nat Genet. 2018 & 0.03 & 0.03 & $1.04(0.98-1.1)$ & $2.13 \mathrm{E}-01$ \\
\hline rs11214775 & 11 & $113,807,181$ & G & 0.72 & 1.07 & Schumacher FR, Nat Genet. 2018 & 0.72 & 0.72 & $1(1.02-0.98)$ & $8.81 \mathrm{E}-01$ \\
\hline rs138466039 & 11 & $125,054,793$ & $\mathrm{~T}$ & 0.01 & 1.32 & DV Conti, Nat Genet. 2021 & 0.01 & 0.01 & $0.96(0.88-1.04)$ & $3.15 \mathrm{E}-01$ \\
\hline rs878987 & 11 & $134,266,372$ & G & 0.16 & 1.07 & DV Conti, Nat Genet. 2021 & 0.15 & 0.16 & $0.97(0.95-1)$ & $3.38 \mathrm{E}-02$ \\
\hline rs2066827 & 12 & $12,871,099$ & $\mathrm{~T}$ & 0.77 & 1.06 & DV Conti, Nat Genet. 2021 & 0.77 & 0.77 & $1.01(1.04-0.99)$ & $1.99 \mathrm{E}-01$ \\
\hline rs77216612 & 12 & $12,877,983$ & A & 0.74 & 1.03 & DV Conti, Nat Genet. 2021 & 0.72 & 0.71 & $1.02(1.04-1)$ & $1.24 \mathrm{E}-01$ \\
\hline rs10845938 & 12 & $14,416,918$ & G & 0.58 & 1.06 & DV Conti, Nat Genet. 2021 & 0.54 & 0.55 & $0.98(1-0.96)$ & $2.91 \mathrm{E}-02$ \\
\hline rs80130819 & 12 & $48,419,618$ & A & 0.91 & 1.10 & DV Conti, Nat Genet. 2021 & 0.92 & 0.92 & $0.98(1.02-0.95)$ & $3.22 \mathrm{E}-01$ \\
\hline rs56222401 & 12 & $49,672,714$ & G & 0.27 & 1.08 & DV Conti, Nat Genet. 2021 & 0.25 & 0.25 & $1(0.98-1.03)$ & $8.11 \mathrm{E}-01$ \\
\hline rs113925811 & 12 & $53,308,932$ & A & 0.12 & 1.18 & DV Conti, Nat Genet. 2021 & 0.11 & 0.11 & $1.01(0.98-1.04)$ & $5.68 \mathrm{E}-01$ \\
\hline rs7968403 & 12 & $65,012,824$ & $\mathrm{~T}$ & 0.65 & 1.06 & DV Conti, Nat Genet. 2021 & 0.63 & 0.63 & $1.01(1.03-0.99)$ & $5.11 \mathrm{E}-01$ \\
\hline rs5799921 & 12 & $90,160,530$ & GA & 0.70 & 1.06 & Schumacher FR, Nat Genet. 2018 & 0.72 & 0.72 & $1.01(1.03-0.99)$ & $5.71 \mathrm{E}-01$ \\
\hline rs77121786 & 12 & $102,446,675$ & G & 0.21 & 1.05 & DV Conti, Nat Genet. 2021 & 0.20 & 0.20 & $0.99(0.97-1.01)$ & $4.15 \mathrm{E}-01$ \\
\hline rs1270884 & 12 & $114,685,571$ & A & 0.49 & 1.07 & DV Conti, Nat Genet. 2021 & 0.47 & 0.48 & $0.95(0.93-0.97)$ & $2.13 \mathrm{E}-07$ \\
\hline rs7295014 & 12 & $133,067,989$ & G & 0.33 & 1.05 & DV Conti, Nat Genet. 2021 & 0.33 & 0.33 & $1.01(0.98-1.03)$ & $6.31 \mathrm{E}-01$ \\
\hline rs1327653 & 13 & $51,076,440$ & $\mathrm{~T}$ & 0.25 & 1.04 & DV Conti, Nat Genet. 2021 & 0.26 & 0.25 & $1.07(1.05-1.1)$ & $1.34 \mathrm{E}-10$ \\
\hline rs7489409 & 13 & $73,716,861$ & c & 0.19 & 1.07 & DV Conti, Nat Genet. 2021 & 0.19 & 0.19 & $0.99(0.97-1.02)$ & $6.75 \mathrm{E}-01$ \\
\hline rs7336001 & 13 & $73,995,877$ & G & 0.89 & 1.11 & DV Conti, Nat Genet. 2021 & 0.92 & 0.92 & $1(1.04-0.97)$ & $9.62 \mathrm{E}-01$ \\
\hline rs1004030 & 14 & $23,305,649$ & $\mathrm{~T}$ & 0.58 & 1.05 & DV Conti, Nat Genet. 2021 & 0.57 & 0.57 & $0.99(1.01-0.97)$ & 2.27E-01 \\
\hline rs6571758 & 14 & $37,136,194$ & G & 0.62 & 1.06 & DV Conti, Nat Genet. 2021 & 0.63 & 0.63 & $1(1.02-0.98)$ & $9.20 \mathrm{E}-01$ \\
\hline rs11849126 & 14 & $38,144,592$ & G & 0.69 & 1.04 & DV Conti, Nat Genet. 2021 & 0.70 & 0.70 & $0.99(1.01-0.97)$ & $2.76 \mathrm{E}-01$ \\
\hline rs 8008270 & 14 & $53,372,330$ & c & 0.81 & 1.09 & Schumacher FR, Nat Genet. 2018 & 0.82 & 0.81 & $1.01(1.03-0.98)$ & $5.23 \mathrm{E}-01$ \\
\hline rs8005621 & 14 & $61,106,699$ & G & 0.08 & 1.06 & DV Conti, Nat Genet. 2021 & 0.10 & 0.10 & $1.02(0.99-1.05)$ & $2.19 \mathrm{E}-01$ \\
\hline rs2093202 & 14 & $68,923,908$ & A & 0.61 & 1.04 & DV Conti, Nat Genet. 2021 & 0.60 & 0.60 & $1(1.02-0.98)$ & $9.17 \mathrm{E}-01$ \\
\hline rs767127 & 14 & $69,134,264$ & G & 0.49 & 1.05 & DV Conti, Nat Genet. 2021 & 0.51 & 0.50 & $1.01(1.03-0.99)$ & $4.48 \mathrm{E}-01$ \\
\hline rs8014671 & 14 & $71,092,256$ & G & 0.60 & 1.05 & Schumacher FR, Nat Genet. 2018 & 0.59 & 0.59 & $1(1.02-0.98)$ & $7.86 \mathrm{E}-01$ \\
\hline rs11561564 & 15 & $40,965,044$ & G & 0.86 & 1.07 & DV Conti, Nat Genet. 2021 & 0.85 & 0.85 & $1.01(1.04-0.99)$ & $3.55 \mathrm{E}-01$ \\
\hline rs33984059 & 15 & $56,385,868$ & A & 0.98 & 1.19 & DV Conti, Nat Genet. 2021 & 0.97 & 0.97 & $1.06(1.13-1)$ & $5.47 \mathrm{E}-02$ \\
\hline rs74634457 & 15 & $66,835,704$ & G & 0.28 & 1.05 & DV Conti, Nat Genet. 2021 & 0.25 & 0.25 & $1.02(1-1.04)$ & $7.58 \mathrm{E}-02$ \\
\hline rs12913603 & 15 & $70,668,824$ & A & 0.41 & 1.04 & DV Conti, Nat Genet. 2021 & 0.49 & 0.49 & $1.02(1-1.04)$ & $2.04 \mathrm{E}-02$ \\
\hline rs7188897 & 16 & $54,469,331$ & $\mathrm{~T}$ & 0.36 & 1.05 & DV Conti, Nat Genet. 2021 & 0.35 & 0.35 & $1.01(0.99-1.03)$ & $3.94 \mathrm{E}-01$ \\
\hline rs13380763 & 16 & $54,678,305$ & c & 0.82 & 1.05 & DV Conti, Nat Genet. 2021 & 0.81 & 0.81 & $0.99(1.02-0.97)$ & $6.41 \mathrm{E}-01$ \\
\hline rs11863709 & 16 & $57,654,576$ & c & 0.97 & 1.15 & DV Conti, Nat Genet. 2021 & 0.96 & 0.96 & $0.94(0.99-0.9)$ & $2.48 \mathrm{E}-02$ \\
\hline rs28709974 & 16 & $79,847,632$ & c & 0.06 & 1.09 & DV Conti, Nat Genet. 2021 & 0.05 & 0.04 & $1.08(1.03-1.13)$ & $7.73 \mathrm{E}-04$ \\
\hline rs8052913 & 16 & $82,166,181$ & c & 0.39 & 1.04 & DV Conti, Nat Genet. 2021 & 0.40 & 0.39 & $1.04(1.02-1.06)$ & $3.00 \mathrm{E}-04$ \\
\hline rs684232 & 17 & 618,965 & c & 0.36 & 1.09 & DV Conti, Nat Genet. 2021 & 0.35 & 0.36 & $1(0.98-1.02)$ & $7.51 \mathrm{E}-01$ \\
\hline rs78378222 & 17 & $7,571,752$ & G & 0.02 & 1.26 & DV Conti, Nat Genet. 2021 & 0.01 & 0.01 & $1.15(1.05-1.25)$ & $1.78 \mathrm{E}-03$ \\
\hline rs28441558 & 17 & $7,803,118$ & c & 0.06 & 1.17 & DV Conti, Nat Genet. 2021 & 0.06 & 0.06 & $1.01(0.97-1.06)$ & 4.85E-01 \\
\hline rs72811270 & 17 & $12,585,459$ & A & 0.11 & 1.06 & DV Conti, Nat Genet. 2021 & 0.12 & 0.12 & $1.06(1.03-1.09)$ & 7.13E-05 \\
\hline rs142444269 & 17 & $30,098,749$ & C & 1.00 & 1.07 & Schumacher FR, Nat Genet. 2018 & 0.80 & 0.81 & $0.98(1.01-0.96)$ & $2.12 \mathrm{E}-01$ \\
\hline rs3110641 & 17 & $36,047,417$ & A & 0.22 & 1.06 & DV Conti, Nat Genet. 2021 & 0.22 & 0.22 & $1(0.97-1.02)$ & 7.07E-01 \\
\hline rs11649743 & 17 & $36,074,979$ & G & 0.82 & 1.10 & DV Conti, Nat Genet. 2021 & 0.82 & 0.82 & $1.04(1.06-1.01)$ & 7.09E-03 \\
\hline rs11263763 & 17 & $36,103,565$ & A & 0.55 & 1.22 & DV Conti, Nat Genet. 2021 & 0.53 & 0.52 & $1.05(1.07-1.03)$ & 4.45E-07 \\
\hline rs11650494 & 17 & $47,345,186$ & A & 0.07 & 1.10 & Schumacher FR, Nat Genet. 2018 & 0.09 & 0.09 & $1(0.97-1.04)$ & 8.27E-01 \\
\hline rs2960158 & 17 & $47,380,305$ & $\mathrm{~T}$ & 0.77 & 1.04 & DV Conti, Nat Genet. 2021 & 0.77 & 0.77 & $0.98(1.01-0.96)$ & $1.49 \mathrm{E}-01$ \\
\hline rs2680708 & 17 & $56,456,120$ & G & 0.60 & 1.05 & Schumacher FR, Nat Genet. 2018 & 0.61 & 0.61 & $1(1.02-0.99)$ & $6.48 \mathrm{E}-01$ \\
\hline rs1859962 & 17 & $69,108,753$ & G & 0.49 & 1.17 & Schumacher FR, Nat Genet. 2018 & 0.47 & 0.47 & $0.99(0.97-1.01)$ & $2.48 \mathrm{E}-01$ \\
\hline rs8093601 & 18 & $51,772,473$ & c & 0.43 & 1.05 & Schumacher FR, Nat Genet. 2018 & 0.44 & 0.43 & $1.02(1-1.04)$ & $7.62 \mathrm{E}-02$ \\
\hline rs28607662 & 18 & $53,230,859$ & c & 0.09 & 1.08 & Schumacher FR, Nat Genet. 2018 & 0.09 & 0.09 & $0.94(0.91-0.97)$ & 4.60E-04 \\
\hline rs35283980 & 18 & $56,745,999$ & G & 0.30 & 1.05 & DV Conti, Nat Genet. 2021 & 0.30 & 0.30 & $1.01(0.99-1.03)$ & $5.30 \mathrm{E}-01$ \\
\hline rs11876000 & 18 & $73,035,513$ & $\mathrm{~T}$ & 0.43 & 1.04 & DV Conti, Nat Genet. 2021 & 0.41 & 0.41 & $1(0.98-1.02)$ & $8.21 \mathrm{E}-01$ \\
\hline rs9959454 & 18 & $76,770,820$ & A & 0.74 & 1.09 & DV Conti, Nat Genet. 2021 & 0.73 & 0.73 & $1(1.02-0.98)$ & $8.59 \mathrm{E}-01$ \\
\hline rs11666569 & 19 & $17,214,073$ & c & 0.72 & 1.05 & Schumacher FR, Nat Genet. 2018 & 0.71 & 0.71 & $0.99(1.01-0.97)$ & 3.37E-01 \\
\hline rs118005503 & 19 & $32,167,803$ & G & 0.88 & 1.09 & Schumacher FR, Nat Genet. 2018 & 0.92 & 0.92 & $0.99(1.02-0.96)$ & $5.12 \mathrm{E}-01$ \\
\hline rs59710626 & 19 & $38,548,094$ & G & 0.87 & 1.06 & DV Conti, Nat Genet. 2021 & 0.86 & 0.86 & $0.99(1.01-0.96)$ & $2.87 \mathrm{E}-01$ \\
\hline rs4802297 & 19 & $38,738,130$ & G & 0.50 & 1.10 & DV Conti, Nat Genet. 2021 & 0.49 & 0.48 & $1.02(1-1.04)$ & $7.53 \mathrm{E}-02$ \\
\hline rs11672691 & 19 & $41,985,587$ & G & 0.74 & 1.10 & Schumacher FR, Nat Genet. 2018 & 0.75 & 0.75 & $0.98(1-0.96)$ & $6.56 \mathrm{E}-02$ \\
\hline rs61088131 & 19 & $42,700,947$ & $\mathrm{~T}$ & 0.84 & 1.06 & Schumacher FR, Nat Genet. 2018 & 0.83 & 0.83 & $0.99(1.01-0.96)$ & $2.73 \mathrm{E}-01$ \\
\hline rs61752561 & 19 & $51,361,382$ & G & 0.96 & 1.16 & DV Conti, Nat Genet. 2021 & 0.96 & 0.96 & $1.03(1.08-0.99)$ & $1.78 \mathrm{E}-01$ \\
\hline rs76765083 & 19 & $51,362,715$ & $\mathrm{~T}$ & 0.93 & 1.31 & DV Conti, Nat Genet. 2021 & 0.93 & 0.93 & $1.07(1.11-1.03)$ & $2.45 \mathrm{E}-04$ \\
\hline rs11480453 & 20 & $31,347,512$ & c & 0.58 & 1.04 & DV Conti, Nat Genet. 2021 & 0.60 & 0.60 & $1.01(1.03-0.99)$ & $3.19 \mathrm{E}-01$ \\
\hline rs6141551 & 20 & $34,006,970$ & c & 0.61 & 1.04 & DV Conti, Nat Genet. 2021 & 0.63 & 0.63 & $1.01(1.03-0.99)$ & $3.24 \mathrm{E}-01$ \\
\hline rs73909841 & 20 & $49,548,807$ & $\mathrm{~T}$ & 0.93 & 1.11 & DV Conti, Nat Genet. 2021 & 0.93 & 0.93 & $1.03(1.07-0.99)$ & $1.31 \mathrm{E}-01$ \\
\hline rs6126986 & 20 & $52,464,719$ & c & 0.48 & 1.07 & DV Conti, Nat Genet. 2021 & 0.49 & 0.49 & $1(0.98-1.02)$ & $8.12 \mathrm{E}-01$ \\
\hline rs2427345 & 20 & $61,015,611$ & c & 0.63 & 1.05 & Schumacher FR, Nat Genet. 2018 & 0.63 & 0.63 & $1.04(1.06-1.02)$ & $1.45 \mathrm{E}-04$ \\
\hline rs381331 & 20 & $62,229,989$ & A & 0.62 & 1.05 & DV Conti, Nat Genet. 2021 & 0.61 & 0.61 & $0.99(1.01-0.97)$ & $5.06 \mathrm{E}-01$ \\
\hline rs3787099 & 20 & $62,307,517$ & A & 0.91 & 1.11 & DV Conti, Nat Genet. 2021 & 0.92 & 0.92 & $1.03(1.07-1)$ & $9.53 \mathrm{E}-02$ \\
\hline rs1058319 & 20 & $62,374,389$ & c & 0.87 & 1.12 & DV Conti, Nat Genet. 2021 & 0.88 & 0.87 & $1.02(1.05-0.99)$ & $3.15 \mathrm{E}-01$ \\
\hline rs11701433 & 21 & $40,296,411$ & c & 0.37 & 1.04 & DV Conti, Nat Genet. 2021 & 0.33 & 0.33 & $1.03(1.01-1.05)$ & 4.04E-03 \\
\hline rs61735792 & 21 & $42,866,332$ & A & 0.01 & 1.26 & DV Conti, Nat Genet. 2021 & 0.01 & 0.01 & $0.99(0.91-1.08)$ & $7.93 \mathrm{E}-01$ \\
\hline rs9978557 & 21 & $42,882,462$ & c & 0.90 & 1.10 & DV Conti, Nat Genet. 2021 & 0.91 & 0.91 & $1(1.03-0.97)$ & $9.31 \mathrm{E}-01$ \\
\hline rs1041449 & 21 & $42,901,421$ & G & 0.44 & 1.05 & Schumacher FR, Nat Genet. 2018 & 0.44 & 0.44 & $0.99(0.98-1.01)$ & $5.76 \mathrm{E}-01$ \\
\hline rs9625483 & 22 & $28,888,939$ & A & 0.04 & 1.15 & DV Conti, Nat Genet. 2021 & 0.02 & 0.02 & $1(0.93-1.07)$ & $9.02 \mathrm{E}-01$ \\
\hline rs138708 & 22 & $39,138,332$ & G & 0.98 & 1.14 & DV Conti, Nat Genet. 2021 & 0.98 & 0.98 & $0.95(1.02-0.89)$ & $1.65 \mathrm{E}-01$ \\
\hline rs58133635 & 22 & $40,471,188$ & $\mathrm{~T}$ & 0.29 & 1.07 & Schumacher FR, Nat Genet. 2018 & 0.20 & 0.21 & $0.97(0.95-0.99)$ & $1.19 \mathrm{E}-02$ \\
\hline rs6003062 & 22 & $43,499,741$ & G & 0.94 & 1.17 & DV Conti, Nat Genet. 2021 & 0.93 & 0.93 & $0.98(1.01-0.94)$ & 2.27E-01 \\
\hline rs5759167 & 22 & $43,500,212$ & G & 0.50 & 1.13 & DV Conti, Nat Genet. 2021 & 0.51 & 0.50 & $1.02(1.04-1)$ & $6.01 \mathrm{E}-02$ \\
\hline rs9615099 & 22 & $45,698,149$ & $\mathrm{~T}$ & 0.75 & 1.04 & DV Conti, Nat Genet. 2021 & 0.75 & 0.75 & $1.01(1.03-0.98)$ & $6.49 \mathrm{E}-01$ \\
\hline rs2405942 & 23 & $9,814,135$ & A & 0.78 & 1.05 & Schumacher FR, Nat Genet. 2018 & 0.80 & 0.80 & $0.97(1.01-0.94)$ & $1.23 \mathrm{E}-01$ \\
\hline rs17321482 & 23 & $11,482,634$ & c & 0.86 & 1.06 & DV Conti, Nat Genet. 2021 & 0.87 & 0.87 & $0.99(1.03-0.95)$ & $5.58 \mathrm{E}-01$ \\
\hline rs5945572 & 23 & $51,229,683$ & A & 0.36 & 1.23 & Gudmundsson J, Nat Genet. 2008 & 0.37 & 0.37 & $1(0.97-1.03)$ & $9.74 \mathrm{E}-01$ \\
\hline rs2807031 & 23 & $52,896,949$ & c & 0.18 & 1.06 & Schumacher FR, Nat Genet. 2018 & 0.18 & 0.18 & $1(0.97-1.04)$ & $9.69 \mathrm{E}-01$ \\
\hline rs5919432 & 23 & $67,021,550$ & $\mathrm{~T}$ & 0.80 & 1.04 & Schumacher FR, Nat Genet. 2018 & 0.82 & 0.81 & $1.06(1.1-1.02)$ & $1.33 \mathrm{E}-03$ \\
\hline
\end{tabular}

\begin{tabular}{|c|c|c|c|}
\hline 0.69 & 0.68 & $1.03(1.06-1.01)$ & 0.01 \\
\hline 0.57 & 0.55 & 1.09 (1.12-1.06) & 1.30E-11 \\
\hline 0.03 & 0.03 & $1.1(1.02-1.18)$ & 0.01 \\
\hline 0.73 & 0.72 & $1.05(1.08-1.02)$ & $8.89 \mathrm{E}-04$ \\
\hline 0.02 & 0.01 & $1.33(1.21-1.47)$ & $5.76 \mathrm{E}-09$ \\
\hline 0.16 & 0.16 & $1.04(1.01-1.08)$ & 0.01 \\
\hline 0.77 & 0.77 & $1.05(1.08-1.02)$ & $2.25 \mathrm{E}-03$ \\
\hline 0.72 & 0.71 & $1.02(1.05-0.99)$ & 0.21 \\
\hline 0.55 & 0.54 & $1.04(1.07-1.02)$ & $7.16 \mathrm{E}-04$ \\
\hline 0.93 & 0.92 & $1.1(1.15-1.05)$ & $7.66 \mathrm{E}-05$ \\
\hline 0.26 & 0.25 & $1.08(1.05-1.11)$ & $2.61 \mathrm{E}-07$ \\
\hline 0.13 & 0.11 & $1.18(1.14-1.23)$ & $1.23 \mathrm{E}-18$ \\
\hline 0.65 & 0.63 & $1.06(1.09-1.04)$ & $3.36 \mathrm{E}-06$ \\
\hline 0.73 & 0.72 & $1.06(1.09-1.03)$ & $2.02 \mathrm{E}-05$ \\
\hline 0.21 & 0.20 & $1.04(1.01-1.07)$ & 0.01 \\
\hline 0.49 & 0.48 & $1.05(1.03-1.08)$ & 3.49E-05 \\
\hline 0.35 & 0.33 & $1.08(1.06-1.11)$ & $6.91 \mathrm{E}-10$ \\
\hline 0.26 & 0.25 & $1.04(1.01-1.07)$ & 0.01 \\
\hline 0.20 & 0.19 & $1.08(1.05-1.12)$ & $3.41 \mathrm{E}-07$ \\
\hline 0.92 & 0.92 & $1.09(1.14-1.04)$ & $1.73 \mathrm{E}-04$ \\
\hline 0.58 & 0.57 & $1.04(1.07-1.02)$ & $6.42 \mathrm{E}-04$ \\
\hline 0.64 & 0.63 & $1.05(1.07-1.02)$ & 4.29E-04 \\
\hline 0.71 & 0.70 & $1.04(1.07-1.01)$ & 4.24E-03 \\
\hline 0.83 & 0.81 & 1.11 (1.14-1.07) & $4.29 \mathrm{E}-10$ \\
\hline 0.10 & 0.10 & $1.06(1.02-1.1)$ & $3.57 \mathrm{E}-03$ \\
\hline 0.60 & 0.60 & $1.03(1.05-1)$ & 0.05 \\
\hline 0.52 & 0.50 & $1.05(1.08-1.03)$ & $1.88 \mathrm{E}-05$ \\
\hline 0.61 & 0.59 & $1.07(1.09-1.04)$ & $6.47 \mathrm{E}-07$ \\
\hline 0.85 & 0.85 & $1.05(1.09-1.02)$ & $4.16 \mathrm{E}-03$ \\
\hline 0.98 & 0.97 & $1.16(1.25-1.07)$ & $3.24 \mathrm{E}-04$ \\
\hline 0.26 & 0.25 & $1.05(1.02-1.08)$ & 4.89E-04 \\
\hline 0.50 & 0.49 & $1.03(1.01-1.06)$ & $8.47 \mathrm{E}-03$ \\
\hline 0.36 & 0.35 & $1.03(1.01-1.06)$ & 0.02 \\
\hline 0.81 & 0.81 & $1.04(1.07-1.01)$ & 0.01 \\
\hline 0.96 & 0.96 & $1.02(1.09-0.96)$ & 0.55 \\
\hline 0.05 & 0.04 & $1.12(1.06-1.18)$ & $1.27 \mathrm{E}-04$ \\
\hline 0.40 & 0.39 & $1.04(1.02-1.07)$ & $1.42 \mathrm{E}-03$ \\
\hline 0.37 & 0.35 & $1.09(1.06-1.12)$ & $3.17 \mathrm{E}-11$ \\
\hline 0.01 & 0.01 & $1.26(1.13-1.39)$ & $1.40 \mathrm{E}-05$ \\
\hline 0.07 & 0.06 & $1.18(1.13-1.24)$ & $9.59 \mathrm{E}-12$ \\
\hline 0.13 & 0.12 & $1.09(1.05-1.13)$ & 4.23E-06 \\
\hline 0.81 & 0.81 & $1.03(1.07-1)$ & 0.04 \\
\hline 0.22 & 0.22 & $1.05(1.02-1.08)$ & 7.06E-04 \\
\hline 0.84 & 0.82 & $1.14(1.18-1.11)$ & 2.37E-15 \\
\hline 0.57 & 0.52 & $1.21(1.24-1.18)$ & $1.34 \mathrm{E}-50$ \\
\hline 0.10 & 0.09 & $1.13(1.09-1.18)$ & $3.91 \mathrm{E}-09$ \\
\hline 0.77 & 0.77 & $1.01(1.03-0.98)$ & 0.73 \\
\hline 0.62 & 0.61 & $1.03(1.06-1.01)$ & 0.01 \\
\hline 0.50 & 0.47 & $1.14(1.12-1.17)$ & $2.01 \mathrm{E}-27$ \\
\hline 0.44 & 0.43 & $1.02(0.99-1.04)$ & 0.17 \\
\hline 0.09 & 0.09 & $0.99(0.95-1.04)$ & 0.71 \\
\hline 0.30 & 0.30 & $1.01(0.98-1.04)$ & 0.53 \\
\hline 0.42 & 0.41 & $1.04(1.01-1.07)$ & $2.61 \mathrm{E}-03$ \\
\hline 0.74 & 0.73 & $1.06(1.09-1.03)$ & $1.13 \mathrm{E}-05$ \\
\hline 0.72 & 0.71 & $1.07(1.1-1.04)$ & $4.18 \mathrm{E}-06$ \\
\hline 0.92 & 0.92 & $1.05(1.1-1.01)$ & 0.02 \\
\hline 0.86 & 0.86 & $1.02(1.05-0.98)$ & 0.37 \\
\hline 0.51 & 0.48 & $1.11(1.08-1.13)$ & $7.80 \mathrm{E}-16$ \\
\hline 0.76 & 0.75 & $1.07(1.1-1.04)$ & $1.26 \mathrm{E}-06$ \\
\hline 0.83 & 0.83 & $1.01(1.05-0.98)$ & 0.49 \\
\hline 0.96 & 0.96 & $1.1(1.17-1.04)$ & $2.08 \mathrm{E}-03$ \\
\hline 0.95 & 0.93 & $1.43(1.51-1.35)$ & $2.39 \mathrm{E}-39$ \\
\hline 0.61 & 0.60 & $1.03(1.05-1)$ & 0.04 \\
\hline 0.64 & 0.63 & $1.04(1.07-1.02)$ & $1.55 \mathrm{E}-03$ \\
\hline 0.93 & 0.93 & $1.07(1.13-1.02)$ & $4.46 \mathrm{E}-03$ \\
\hline 0.50 & 0.49 & $1.05(1.03-1.08)$ & 4.44E-05 \\
\hline 0.63 & 0.63 & $1.02(1.05-1)$ & 0.10 \\
\hline 0.62 & 0.61 & $1.06(1.09-1.04)$ & $1.15 \mathrm{E}-06$ \\
\hline 0.93 & 0.92 & $1.08(1.14-1.04)$ & $6.42 \mathrm{E}-04$ \\
\hline 0.89 & 0.87 & $1.11(1.16-1.07)$ & $4.19 \mathrm{E}-08$ \\
\hline 0.33 & 0.33 & $1.02(0.99-1.04)$ & 0.23 \\
\hline 0.02 & 0.01 & $1.28(1.16-1.41)$ & $1.46 \mathrm{E}-06$ \\
\hline 0.92 & 0.91 & $1.13(1.19-1.09)$ & $1.35 \mathrm{E}-08$ \\
\hline 0.45 & 0.44 & $1.05(1.03-1.08)$ & $3.61 \mathrm{E}-05$ \\
\hline 0.02 & 0.02 & $1.05(0.96-1.14)$ & 0.32 \\
\hline 0.98 & 0.98 & $1.13(1.23-1.03)$ & $9.17 \mathrm{E}-03$ \\
\hline 0.21 & 0.21 & $1.03(1-1.06)$ & 0.05 \\
\hline 0.94 & 0.93 & $1.22(1.29-1.16)$ & $2.43 \mathrm{E}-14$ \\
\hline 0.53 & 0.50 & $1.13(1.16-1.1)$ & $2.86 \mathrm{E}-23$ \\
\hline 0.75 & 0.75 & $1.04(1.07-1.01)$ & 0.01 \\
\hline 0.82 & 0.80 & $1.12(1.17-1.07)$ & $3.01 \mathrm{E}-07$ \\
\hline 0.88 & 0.87 & $1.09(1.15-1.03)$ & $1.79 \mathrm{E}-03$ \\
\hline 0.40 & 0.36 & $1.18(1.14-1.22)$ & $7.63 \mathrm{E}-21$ \\
\hline 0.19 & 0.18 & $1.08(1.04-1.13)$ & $3.52 \mathrm{E}-04$ \\
\hline 0.82 & 0.81 & $1.09(1.13-1.04)$ & $3.51 \mathrm{E}-04$ \\
\hline
\end{tabular}


sTable 2. Prevalence of lethal and non-lethal PCa by GRS deciles

\begin{tabular}{|c|c|c|c|c|c|c|c|}
\hline \multirow[b]{2}{*}{ GRS (range) } & \multirow[b]{2}{*}{ No. } & \multicolumn{3}{|c|}{ Lethal PCa } & \multicolumn{3}{|c|}{ Non-lethal PCa } \\
\hline & & No. & $\%$ & P-trend & No. & $\%$ & P-trend \\
\hline $\mathrm{GRS}_{\mathrm{BPH}}$ & & & & 0.14 & & & 0.01 \\
\hline$(0,0.704]$ & 19,783 & 61 & $0.31 \%$ & & 1,183 & $5.98 \%$ & \\
\hline$(0.704,0.783]$ & 19,780 & 62 & $0.31 \%$ & & 1,190 & $6.02 \%$ & \\
\hline$(0.783,0.845]$ & 19,792 & 81 & $0.41 \%$ & & 1,248 & $6.31 \%$ & \\
\hline$(0.845,0.902]$ & 19,784 & 62 & $0.31 \%$ & & 1,265 & $6.39 \%$ & \\
\hline$(0.902,0.96]$ & 19,770 & 66 & $0.33 \%$ & & 1,267 & $6.41 \%$ & \\
\hline$(0.96,1.02]$ & 19,782 & 59 & $0.30 \%$ & & 1,283 & $6.49 \%$ & \\
\hline$(1.02,1.09]$ & 19,779 & 67 & $0.34 \%$ & & 1,241 & $6.27 \%$ & \\
\hline$(1.09,1.18]$ & 19,786 & 64 & $0.32 \%$ & & 1,305 & $6.60 \%$ & \\
\hline$(1.18,1.31]$ & 19,779 & 63 & $0.32 \%$ & & 1,210 & $6.12 \%$ & \\
\hline$(1.31,3]$ & 19,775 & 45 & $0.23 \%$ & & 1,313 & $6.64 \%$ & \\
\hline $\mathrm{GRS}_{\mathrm{PCa}}$ & & & & $7.64 \mathrm{E}-47$ & & & $<1 E-299$ \\
\hline$(0,0.242]$ & 20,939 & 17 & $0.08 \%$ & & 330 & $1.58 \%$ & \\
\hline$(0.242,0.343]$ & 20,939 & 28 & $0.13 \%$ & & 605 & $2.89 \%$ & \\
\hline$(0.343,0.443]$ & 20,938 & 41 & $0.20 \%$ & & 737 & $3.52 \%$ & \\
\hline$(0.443,0.551]$ & 20,939 & 44 & $0.21 \%$ & & 867 & $4.14 \%$ & \\
\hline$(0.551,0.677]$ & 20,938 & 64 & $0.31 \%$ & & 1,026 & $4.90 \%$ & \\
\hline$(0.677,0.831]$ & 20,939 & 49 & $0.23 \%$ & & 1,203 & $5.75 \%$ & \\
\hline$(0.831,1.04]$ & 20,938 & 75 & $0.36 \%$ & & 1,429 & $6.82 \%$ & \\
\hline$(1.04,1.36]$ & 20,939 & 80 & $0.38 \%$ & & 1,707 & $8.15 \%$ & \\
\hline$(1.36,1.97]$ & 20,938 & 108 & $0.52 \%$ & & 2,124 & $10.14 \%$ & \\
\hline$(1.97,51]$ & 20,939 & 161 & $0.77 \%$ & & 3,259 & $15.56 \%$ & \\
\hline
\end{tabular}


It is made available under a CC-BY-NC 4.0 International license .

sTable 3. Nearest genes in the chromosomal regions that are associated with both BPH and PCa risk

\begin{tabular}{|c|c|c|c|c|}
\hline rsID & $\mathrm{CHR}$ & Position & Nearest genes & Gene Name \\
\hline rs636291 & 1 & $10,556,097$ & PEX14 & peroxisomal biogenesis factor 14(PEX14) \\
\hline rs14784749€ & $€ 1$ & $155,118,588$ & DPM3 & dolichyl-phosphate mannosyltransferase subunit 3(DPM3) \\
\hline rs11902236 & 2 & $10,117,868$ & GRHL1 & grainyhead like transcription factor $1(\mathrm{GRHL} 1)$ \\
\hline rs2028900 & 2 & $85,767,735$ & MAT2A & methionine adenosyltransferase 2A(MAT2A) \\
\hline rs76832527 & 2 & $242,157,241$ & ANO7 & anoctamin 7(ANO7) \\
\hline rs2811476 & 3 & $127,898,501$ & EEFSEC & eukaryotic elongation factor, selenocysteine-tRNA specific(EEFSEC) \\
\hline rs7650602 & 3 & $141,147,414$ & ZBTB38 & zinc finger and BTB domain containing 38(ZBTB38) \\
\hline rs2293607 & 3 & $169,482,335$ & TERC & telomerase RNA component(TERC) \\
\hline rs2736098 & 5 & $1,294,086$ & TERT & telomerase reverse transcriptase(TERT) \\
\hline rs381949 & 5 & $1,322,468$ & CLPTM1L & CLPTM1 like(CLPTM1L) \\
\hline rs4976790 & 5 & $177,968,915$ & COL23A1 & collagen type XXIII alpha 1 chain(COL23A1) \\
\hline rs200476 & 6 & $27,768,348$ & $\begin{array}{l}\text { HIST1H2BL } \\
\text { LOC100131289 }\end{array}$ & $\begin{array}{l}\text { histone cluster } 1 \text { H2B family member I(HIST1H2BL) } \\
\text { uncharacterized LOC100131289(LOC100131289) }\end{array}$ \\
\hline rs130067 & 6 & $31,118,511$ & CCHCR1 & coiled-coil alpha-helical rod protein 1(CCHCR1) \\
\hline rs3129859 & 6 & $32,400,939$ & $\begin{array}{l}\text { BTNL2 } \\
\text { HLA-DRA }\end{array}$ & $\begin{array}{l}\text { butyrophilin like } 2 \text { (BTNL2) } \\
\text { major histocompatibility complex, class II, DR alpha(HLA-DRA) }\end{array}$ \\
\hline rs9472120 & 6 & $43,709,785$ & $\begin{array}{l}\text { MRPS18A } \\
\text { VEGFA }\end{array}$ & $\begin{array}{l}\text { mitochondrial ribosomal protein S18A(MRPS18A) } \\
\text { vascular endothelial growth factor A(VEGFA) }\end{array}$ \\
\hline rs339331 & 6 & $117,210,052$ & RFX6 & regulatory factor X6(RFX6) \\
\hline rs35389879 & 7 & $21,812,043$ & DNAH11 & dynein axonemal heavy chain 11(DNAH11) \\
\hline rs17621345 & 7 & $40,875,192$ & SUGCT & succinyl-CoA:glutarate-CoA transferase(SUGCT) \\
\hline rs6955627 & 7 & $92,577,760$ & $\begin{array}{l}\text { LOC101927497 } \\
\text { SAMD9 }\end{array}$ & $\begin{array}{l}\text { uncharacterized LOC101927497(LOC101927497) } \\
\text { sterile alpha motif domain containing 9(SAMD9) }\end{array}$ \\
\hline rs2928679 & 8 & $23,438,975$ & $\begin{array}{l}\text { NKX3-1 } \\
\text { SLC25A37 }\end{array}$ & $\begin{array}{l}\text { NK3 homeobox } 1(\mathrm{NKX} 3-1) \\
\text { solute carrier family } 25 \text { member } 37(\text { SLC25A37) }\end{array}$ \\
\hline rs1016343 & 8 & $128,093,297$ & PRNCR1 & prostate cancer associated non-coding RNA 1(PRNCR1) \\
\hline rs620861 & 8 & $128,335,673$ & CASC21 & cancer susceptibility candidate 21 (non-protein coding)(CASC21) \\
\hline rs6983267 & 8 & $128,413,305$ & CCAT2 & colon cancer associated transcript 2 (non-protein coding)(CCAT2) \\
\hline rs11986220 & 8 & $128,531,689$ & $\begin{array}{l}\text { CASC11 } \\
\text { CASC8 }\end{array}$ & $\begin{array}{l}\text { cancer susceptibility candidate } 11 \text { (non-protein coding)(CASC11) } \\
\text { cancer susceptibility candidate } 8 \text { (non-protein coding)(CASC8) }\end{array}$ \\
\hline rs4451364 & 9 & $109,532,734$ & $\begin{array}{l}\text { LINC01505 } \\
\text { ZNF462 }\end{array}$ & $\begin{array}{l}\text { long intergenic non-protein coding RNA 1505(LINC01505) } \\
\text { zinc finger protein 462(ZNF462) }\end{array}$ \\
\hline rs10788167 & 10 & $123,054,018$ & $\begin{array}{l}\text { FGFR2 } \\
\text { MIR5694 }\end{array}$ & $\begin{array}{l}\text { fibroblast growth factor receptor 2(FGFR2) } \\
\text { microRNA 5694(MIR5694) }\end{array}$ \\
\hline rs72878024 & 11 & 199,492 & ODF3 & outer dense fiber of sperm tails 3(ODF3) \\
\hline rs12785905 & 11 & $66,951,965$ & KDM2A & lysine demethylase $2 \mathrm{~A}(\mathrm{KDM} 2 \mathrm{~A})$ \\
\hline rs878987 & 11 & $134,266,372$ & B3GAT1 & beta-1,3-glucuronyltransferase 1(B3GAT1) \\
\hline rs10845938 & 12 & $14,416,918$ & $\begin{array}{l}\text { ATF7IP } \\
\text { GRIN2B }\end{array}$ & $\begin{array}{l}\text { activating transcription factor } 7 \text { interacting protein(ATF7IP) } \\
\text { glutamate ionotropic receptor NMDA type subunit } 2 B(G R I N 2 B)\end{array}$ \\
\hline rs1270884 & 12 & $114,685,571$ & $\begin{array}{l}\text { RBM19 } \\
\text { TBX5 }\end{array}$ & $\begin{array}{l}\text { RNA binding motif protein 19(RBM19) } \\
\text { T-box 5(TBX5) }\end{array}$ \\
\hline rs8853 & 12 & $115,108,907$ & TBX3 & T-box 3(TBX3) \\
\hline rs1327653 & 13 & $51,076,440$ & $\begin{array}{l}\text { DLEU1-AS1 } \\
\text { ST13P4 }\end{array}$ & $\begin{array}{l}\text { DLEU1 antisense RNA 1(DLEU1-AS1) } \\
\text { suppression of tumorigenicity } 13 \text { (colon carcinoma) (Hsp70 interacting protein) pseudogene 4(ST13P4) }\end{array}$ \\
\hline rs12913603 & 15 & $70,668,824$ & $\begin{array}{l}\text { SALRNA3 } \\
\text { TLE3 }\end{array}$ & $\begin{array}{l}\text { senescence associated long non-coding RNA 3(SALRNA3) } \\
\text { transducin like enhancer of split 3(TLE3) }\end{array}$ \\
\hline rs11863709 & 16 & $57,654,576$ & ADGRG1 & adhesion G protein-coupled receptor G1(ADGRG1) \\
\hline rs28709974 & 16 & $79,847,632$ & $\begin{array}{l}\text { LINC01229 } \\
\text { LOC102724084 }\end{array}$ & $\begin{array}{l}\text { long intergenic non-protein coding RNA 1229(LINC01229) } \\
\text { uncharacterized LOC102724084(LOC102724084) }\end{array}$ \\
\hline rs8052913 & 16 & $82,166,181$ & $\begin{array}{l}\text { HSD17B2 } \\
\text { MPHOSPH6 }\end{array}$ & $\begin{array}{l}\text { hydroxysteroid 17-beta dehydrogenase 2(HSD17B2) } \\
\text { M-phase phosphoprotein 6(MPHOSPH6) }\end{array}$ \\
\hline rs78378222 & 17 & $7,571,752$ & TP53 & tumor protein p53(TP53) \\
\hline rs72811270 & 17 & $12,585,459$ & LOC101928418 & uncharacterized LOC101928418(LOC101928418) \\
\hline rs11649743 & 17 & $36,074,979$ & HNF1B & HNF1 homeobox B(HNF1B) \\
\hline rs9958656 & 18 & $19,904,144$ & $\begin{array}{l}\text { CTAGE1 } \\
\text { GATA6 }\end{array}$ & $\begin{array}{l}\text { cutaneous T-cell lymphoma-associated antigen } 1 \text { (CTAGE1) } \\
\text { GATA binding protein } 6(\text { GATA6) }\end{array}$ \\
\hline rs28607662 & 18 & $53,230,859$ & TCF4 & transcription factor $4(\mathrm{TCF} 4)$ \\
\hline rs76765083 & 19 & $51,362,715$ & KLK3 & kallikrein related peptidase $3(\mathrm{KLK} 3)$ \\
\hline rs2427345 & 20 & $61,015,611$ & $\begin{array}{l}\text { GATA5 } \\
\text { RBBP8NL }\end{array}$ & $\begin{array}{l}\text { GATA binding protein 5(GATA5) } \\
\text { RBBP8 N-terminal like(RBBP8NL) }\end{array}$ \\
\hline rs11701433 & 21 & $40,296,411$ & LOC400867 & uncharacterized LOC400867(LOC400867) \\
\hline rs58133635 & 22 & $40,471,188$ & $\begin{array}{l}\text { LOC100130899 } \\
\text { TNRC6B }\end{array}$ & $\begin{array}{l}\text { uncharacterized LOC100130899(LOC100130899) } \\
\text { trinucleotide repeat containing 6B(TNRC6B) }\end{array}$ \\
\hline rs5919432 & 23 & $67,021,550$ & $\begin{array}{l}\text { AR } \\
\text { OPHN1 }\end{array}$ & $\begin{array}{l}\text { androgen receptor(AR) } \\
\text { oligophrenin } 1(\mathrm{OPHN} 1)\end{array}$ \\
\hline
\end{tabular}


medRxiv preprint doi: https://doi.org/10.1101/2021.12.10.21267604; this version posted December 14, 2021. The copyright holder for this preprint (which was not certified by peer review) is the author/funder, who has granted medRxiv a license to display the preprint in perpetuity.

It is made available under a CC-BY-NC 4.0 International license .

sTable 4. Enrichment analysis of nearest genes in the chromosomal regions associated with both BPH and PCa (6,879 genes in KEGG)

\begin{tabular}{llll}
\hline KEGG pathway (No. genes in the pathway) & No. (\%) genes observed & Observed genes & P-Fisher \\
\hline Prostate cancer (88) & $5(7.7 \%)$ & $A R$, PLK3, TP53, FGFR2, NKX3-1 & $4.10 \mathrm{E}-06$ \\
Pathways in cancer (393) & $6(9.2 \%)$ & AR, KLK3, TP53, FGFR2, NKX3-1, VEGFA & $6.50 \mathrm{E}-04$ \\
Systemic lupus erythematosus (134) & $3(4.6 \%)$ & HIST1H2BL, HLA-DRA, GRIN2B & 0.15 \\
Maturity onset diabetes of the young (26) & $2(3.1 \%)$ & RFX6, HNF1B & $6.50 \mathrm{E}-03$ \\
Huntington's disease (192) & $3(4.6 \%)$ & DNAH11, TP53, GRIN2B & $2.50 \mathrm{E}-03$ \\
\hline
\end{tabular}

